\title{
Maceral study to determine the desorbed gas content in the Upper Cretaceous coals of the Landázuri area, Middle Magdalena Valley Basin, Colombia
}

Clara Guatame ( $\nabla$ clara_guatame@hotmail.com )

Servicio Geológico Colombiano https://orcid.org/0000-0003-3101-6534

Marco Rincón

Servicio Geológico Colombiano

Mauricio Bermúdez

Universidad Pedagogica y Tecnologica de Colombia

\section{Case study}

Keywords: Middle Magdalena Valley, coal, petrology, maceral, gas, principal component analysis (PCA)

Posted Date: September 17th, 2021

DOl: https://doi.org/10.21203/rs.3.rs-885749/v1

License: (c) (1) This work is licensed under a Creative Commons Attribution 4.0 International License.

Read Full License 


\section{Maceral study to determine the desorbed gas \\ 2 content in the Upper Cretaceous coals of the \\ 3 Landázuri area, Middle Magdalena Valley \\ 4 Basin, Colombia}

5 Clara Guatame ${ }^{\mathrm{a}}$, Marco Rincón ${ }^{\mathrm{b}}$, Mauricio Bermúdez

6

${ }^{a, b}$ Servicio Geológico Colombiano, Bogotá, Colombia

$8{ }^{c}$ School of Geological Engineering, Universidad Pedagógica y Tecnológica de

9 Colombia- UPTC

10 a cguatame@sgc.gov.com, clara_guatame@hotmail.com

11 b mrincon@sgc.gov.co

$12{ }^{\mathrm{c}}$ mauricio.bermudez@uptc.edu.co

13 ORCID 0000-0003-3101-6534; 0000-0002-4896-5384; 0000-0003-0584-4790

15 Abstract

16 For several decades, some coal petrographic properties have been proposed as important 17 parameters in the methane gas sorption processes. In this contribution, the petrographic variables

18 (Vitrinite Ratio, Inertinite Ratio, the petrographic indexes (Gelification Index, Groundwater Index,

19 Tissue Preservation Index, Vegetation Index, Vitrinite/Inertinite ratio, and the Vitrinite

20 Reflectance were evaluated according to the maceral preservation and were related with the

21 desorbed gas content. Twenty-five coal seams obtained from the drill cores of two wells in the

22 Landázuri Area-Valle Medio del Magdalena basin were analyzed. The coal samples were grouped

23 according to gas content using principal component analysis (PCA). The petrographic results were

24 analyzed by linear regression and multiple regression. The Medium Volatile Bituminous to Low

25 Volatile Bituminous coals from Landázuri 1 are twice as high in gas content that the High Volatile

26 Bituminous A to Medium Volatile Bituminous coals from Landázuri 2. The volume percentage

27 and the preservation degree macerals are related closely to the gas content and the pore's size

28 involved in the sorption process. The Inertinite is the maceral group related with the highest gas

29 content groups in Landázuri (600 SCF-Standard Cubic Feet/ton, $300 \mathrm{SCF} /$ ton), while the other

30 groups show the correspondence with the vitrinite macerals. The syngenetic and diagenetic origin

31 of the pyrite contributes microporosity to the desorption process, while the pyrite epigenetic by its

32 size reduces it. The petrographic indexes reveal that the Upper Cretaceous coals were developed in

33 swampy or lacustrine continental basins- limnic facies.

34 Keywords: Middle Magdalena Valley, coal, petrology, maceral, gas, principal

35 component analysis (PCA) 


\section{Introduction}

38 The Energy Resources group of the Servicio Geológico Colombiano has been

39 conducting Coal Bed Methane (CBM) studies since 2011 in five Colombian coal

40 areas. In 2016, total ash-free gas contents (37.54- 818.14 SCF/ton) were obtained

41 from coal seams of the Umir Formation-Upper Cretaceous of the Landázuri area-

42 Middle Magdalena Valley Basin. The resources potential was calculated as 360.47

43 BCF (Billion Cubic Feet) (Ortíz et al. 2016). Gas chromatography analysis

44 indicated that the methane gas percentage is between $41.90 \%$ and $92.50 \%$ of the

45 gas measured in the analyzed coal seams (Ortíz et al. 2016). The relationship

46 between methane gas accumulation mechanisms and coal composition has led to

47 the examination of certain measurements of interest in petrological analyses,

48 which act during the process of hydrocarbon sorption.

49 The largest volume of CBM resources worldwide is found in the countries of

50 Russia, China, United States, Canada, Australia, Indonesia, Poland, Germany, and

51 France, corresponding to 4000-7011 trillion cubic feet, of which 1060-1500

52 trillion cubic feet are considered recoverable. The United States has been the

53 leader in CBM production since the '90s with an upward trend, with 2008 being

54 the only decrease year; while China and Australia substantially increased their

55 own CBM production in 2010 and 2014, respectively, focusing on high-rank coals

56 and with interest in natural gas liquids (NGL) production. Thus, it is expected that

57 Australia will soon take the top spot on the global market, with India occupying

585 th place (Mastalerz and Drobniak 2020).

60 In Colombia, coal is a primary source for electricity generation, being also the

61 largest producer in South America, with 1.46 exajoules (EJ)- 50 million tonnes in

622020 (BP 2021). Coal reserves reported during 2020 equaled 4554 million tonnes

63 of bituminous and anthracite coals (BP 2021). The Middle Magdalena Valley

64 basin has been in the sights of explorers because of its high hydrocarbon potential.

65 The first oil field discovered in the country is located. At the northeast of the basin

66 is located the Opón River- Landázuri coal area. Its potential is 201,012,049

67 million tonnes $(\mathrm{Mt})$ of thermal coal and 137,156,216 Mt of metallurgical coal

68 from the Upper Cretaceous Umir Formation (Monroy and Sandoval 2014). In

69 terms of CBM reserve estimation, the analysis of two boreholes (Landázuri 1 and

70 Landázuri 2) allowed estimating a potential of 360.47 Billion Cubic Feet (BCF) 
71 (Ortíz et al. 2016). The detailed petrological analyses are vital to know the coal

72 composition and the geological mechanisms of accumulation of coal-associated

73 gas in an area with high tectonic complexity.

75 Coal petrology studies began in Colombia from the year 2000 onwards in

76 different areas of the country (Castaño and Gómez 2001; Guatame and Sarmiento

77 2004; Mejía et al. 2006; Blandón 2007; Gómez and López 2017; Guo et al. 2018;

78 Akinyemi et al. 2020; Guatame and Rincón 2021, among others) mainly to

79 contribute to the knowledge of the petrographic composition and the definition of

80 the sedimentary environment.

82 Studies on CBM potential began in 1990 led by governmental entities and 83 universities, including, Agencia Nacional de Hidrocarburos- ANH, Ecopetrol84 Instituto Colombiano del Petróleo (ICP), Agencia Nacional de Minería (ANM), 85 Servicio Geológico Colombiano (SGC), Ministerio de Minas y Energía (MME), 86 Unidad de Planeación Minero Energética- UPME, Escuela de Administración, 87 Finanzas e Instituto Tecnológico-EAFIT Universidad Industrial de Santander88 UIS, Universidad Pedagógica y Tecnológica de Colombia- UPTC, and 89 Universidad Nacional de Colombia sede Medellín, among others (Mariño et al. 90 2015). In addition, the Drummond company stands out for carrying out the first

91 CBM exploitation project in the Cesar Ranchería basin. In the before-mentioned 92 studies, no petrological analysis of coal was performed, and in many of them, an 93 analysis of the influence of coal composition on methane gas content was not 94 rigorously elaborated. However, Mariño and Mojica (2014) carried out a 95 petrographic study in the Amagá basin on low-rank coals and concluded that the 96 vitrinite maceral group is the most influential component for gas adsorption and 97 that the mineral matter content evidences an inverse relationship concerning gas 98 content since it acts as a diluent.

100 Furthermore, under a significant number of studies from the sedimentary basins of 101 China, Australia, Canada, and the United States, crucial variables that influence 102 the sorption capacity of methane gas in coal seams to have been defined: the range 103 and burial depth (e.g., Laxminarayana and Crosdale 1999; Wang et al. 2011;

104 Bustin and Bustin 2016; Busch et al. 2019), the maceral composition (e.g. Yao et 
105 al. 2009, Jian et al. 2015; Li et al. 2016; Hou et al. 2017), the pore size 106 distribution (micro, macro, mesoporous), and the specific surface area (e.g., 107 Crosdale et al. 1998; Laxminarayana and Crosdale 1999; Chalmers and Bustin 108 2007; Busch and Gensterblum 2011; Li et al. 2014; Jian et al. 2015). According to 109 the notion that the most frequent maceral groups are Vitrinite and Inertinite, some 110 authors claim that macerals of the Vitrinite group present higher adsorption 111 capacity and higher desorption rate (e.g., Crosdale et al. 1998; Laxminarayana and 112 Crosdale 1999, among others). Others (Wang et al. 2011; Jian et al. 2015; Wang 113 et al. 2018; among others) express that it is the inertinitic macerals that have this 114 capacity. Regarding the mineral matter content resulting from the coal formation 115 processes, some authors indicate its relationship with the gas adsorption capacity 116 (e.g., Laxminarayana 1999; Moore 2012; Raharjo et al. 2018), with the desorption 117 rate (e.g., Crosdale et al. 1998; Li et al. 2017) and with the porosity contribution 118 in the sorption process (e.g., Bertrand 1989).

120 Colombian research on CBM potential has targeted different coal areas and has 121 yet to properly analyze the close relationship between the gas contents obtained 122 and the origin of the coal (Mariño and Mojica 2014). The research challenge is to 123 define which are the inherent physical properties of coals (rank, maceral 124 composition, mineral composition, facies, pore structure) involved in the higher or 125 lower gas content, which is necessary for the exploration of new economic 126 alternatives for coal deposits.

128 The main purpose of this study is to establish the relationship between the 129 measured gas content (SCF/ton) in the coal seams of the Landázuri 1 and 130 Landázuri 2 wells, and the maturity degree of the petrographic composition, and 131 in particular, the coal constituents that by their nature, preservation and the 132 occurrence mode, contribute to gas sorption. This research also aims to define a 133 methodology in exploratory studies of methane gas. Coal petrology is 134 implemented as a prognostic discipline that provides the necessary elements in the 135 CBM potential promising areas for the identification and prevention of gas-related 136 accidents in mining operations. Petrophysical studies of porosity and permeability 137 are not in the scope of this study. 


\section{Geological setting}

140 The Landázuri 1 and 2 wells are located in the Armas syncline of the Río Opón-

141 Landázuri coal-bearing area (Landázuri- Vélez area) along the eastern margin of

142 the Middle Magdalena Valley basin (Fig.1). The area is affected by two regional

143 thrust fault systems resulting from the Mesozoic rifting of northern Colombia and

144 its subsequent reactivation during the Cenozoic for the time of the Andean

145 orogeny (e.g., Colleta et al. 1990; Dengo and Covey 1993; Cooper et al. 1995, for

146 more references see Sarmiento et al. 2015). The oblique compressional stress

147 generated structures and reactivated transpressive faults generating second-order

148 folds oblique to these main faults (Gómez et al. 2008 in Ortíz et al. 2016).

150 In the research area, the La Salina fault system corresponds to a reverse system

151 with westward vergence spans from south to north in the western flank of the De

152 Armas syncline putting in contact Maastrichtian rocks with those dated Lower to

153 Middle Oligocene (Sarmiento et al. 2015; Ortíz et al. 2016). The Landázuri Fault

154 system with westward vergence corresponds to a thrust scale of the La Salina

155 Fault, located on the eastern flank of the syncline where Turonian rocks overlying

156 Maastrichtian rocks. (Ortíz et al. 2016). The Armas syncline corresponds to a

157 broad and asymmetric fold with southeast-northwest direction and widening on

158 the eastern flank (Ortíz et al. 2016).

160 In the Upper Cretaceous rocks, the roughly 1400 meters thick Umir formation

161 (Gómez et al. 2008 in Ortíz et al. 2016; Sarmiento et al. 2015) was deposited in a

162 restricted marine environment with the development of marshy areas that

163 accumulate organic matter for the subsequent production of economically

164 exploitable coal seams (Sarmiento et al. 2015). The unit consists of three levels. In

165 the Landázuri area the thickness is tectonically affected and the lower level of the

166 Umir Formation or La Renta Formation- (Terraza 2020) is not evident. The

167 middle level is 400 meters thick composed of a gray claystone succession with

168 gray to light brown silty claystone intercalations and sporadic levels of very fine

169 to fine-grained arenite. The segment has coal seams with variable thicknesses

170 ranging from a few centimeters to 3 meters. The upper level is 400 meters thick

171 and consists of a succession of light brown, intercalated with gray clayey

172 siltstones and coal seams of fine-grained arenite (Ortíz et al. 2016). 
173 The Landázuri 1 well is located on the eastern flank of the De Armas syncline in 174 the southern sector, crossing the upper and middle levels of the Umir Formation.

175 Fourteen coal seams numbered from base to top (M3- M23) were analyzed 176 according to the stratigraphic position with variable thicknesses ranging from 0.40 $177 \mathrm{~m}$ to $2.63 \mathrm{~m}$ (Ortíz et al. 2016). The Landázuri 2 well is located northwest on the 178 western flank of the syncline. On the middle level, eleven coal seams were 179 identified (M2- M18) with thicknesses varying from $0.55 \mathrm{~m}$ to 2.38 (Ortíz et al. 180 2016) (Fig. 1 and 2).

\section{Experimental methods}

\section{Gas measurement method}

184 The gas desorption measurement of the cores was performed through the direct 185 canister method, as desorbed and residual gas as a function of time and under

186 pressure and temperature conditions that simulate the reservoir characteristics in a 187 laboratory environment (Ortíz et al. 2016).

189 The coal degassing (lost gas) on the drilling cores consisted of the water 190 displacement measurement in a volumetric column. After 24 hours, the 191 measurement of desorbed gas was started in hermetically sealed canisters with in 192 situ pressure and temperature control or calculated with the geothermal gradient. 193 The absorbed gas by the coal matrix was calculated from the residual gas in 194 pulverized samples (60 mesh) in a container for gas mixture or in a hermetically 195 sealed ball mill connected to a manometer. The measurements obtained were 196 processed using the TerraGas software (https://terrasolid.com/product/tgas/), 197 which performs pressure, temperature, and gas volume corrections, measured 198 from the sample weight, canister volume, volume of inert material introduced, and 199 density (ISO Standard 17892-2:2014). The cumulative gas desorption curve points 200 out the intervals of lost, measured and residual gas by plotting the cumulative gas 201 content vs time (ft/ton Vs $\sqrt{\text { hours}) ~(F i g . ~ 3) . ~ T h e ~ a s h ~ c o r r e c t i o n ~ w a s ~ p e r f o r m e d ~}$ 202 finally obtaining the ash-free total gas content. (Ortíz et al. 2016). Gas 203 chromatography was used to determine the percentage of gas mixture and 204 methane gas in the measured contents of each sample (Ortíz et al. 2016). 
206 Petrographic methods

207 The reflectance values (Ro) were obtained by professionals from the Servicio

208 Geológico Colombiano's Laboratory of Characterization, Processing and

209 Research of Coal and Energetic Materials, according to the ASTM D2798-05

210 standard. The identification and classification of the macerals was carried out

211 according to Standard D2799-05 with the reading of 500 points in each specimen

212 and its corresponding repeatability. A Leitz Ortholux II POLMK microscope was

213 used with a magnification of 400x, a dot counter, and a mechanical stage that

214 advances with fixed increments. The macerals classification used the

215 nomenclature compiled by $\operatorname{ICCP}(1998,2001)$ and the Pickel et al. (2017)

216 nomenclature for the Liptinite group. The macerals of the Vitrinite and Inertinite

217 groups were differentiated according to their degree of preservation (Lamberson

218 and Bustin 1993). Structured Vitrinite is composed of the Telovitrinite and

219 Gelovitrinite subgroup and the degraded Vitrinite is constituted of macerals of the

220 Detrovitrinite subgroup. Preserved Fusinite and Semifusinite were counted as

221 preserved inert, and the other macerals group make up the degraded inerts

222 subgroup. The mineral matter was quantified as clay, pyrite, and others. The

223 Pyrite classification was according to its formation process in coal as syngeneic,

224 diagenetic and epigenetic. The coal facies were obtained from the application of

225 petrographic indices proposed by Diessel (1986) and Calder et al. (1991).

\section{Statistical methods}

228 To avoid the analyst's subjectivity when classifying coal seams groups, cluster 229 analysis was used, based on K-Means Clustering (Hartigan and Wong 1979). This

230 procedure attempts to discriminate groups of relatively homogeneous cases, based

231 on certain selected properties. In our particular case, the following variables were

232 used: RV, RI, GI, GWI, TPI, VI, V/I. Pseudocode written in R was used, which

233 allows a large number of cases to be considered. However, it is often the case that

234 the algorithm requires the user to specify the number of clusters. For this, the

235 initial number of the clusters was obtained from the Elbow Method (Lloyd 1982).

236 In the algorithm, the initial centroids of the clusters can be specified, and the 
237 cluster centroids are updated iteratively. The algorithm used also allows automatic

238 selection of the number of clusters based on Bayesian information criteria

239 (Schwartz 1978). It can also store cluster labels for each measurement, distance

240 information, and the centers of the final clusters. The relative size of the statistics

241 provides information about the contribution of each variable to the separation of

242 the clusters. Once the classification is performed; the results are presented in the

243 form of dendograms. The $\mathrm{R}$ correlation factor is analyzed as a linear regression

244 product from the petrographic variables concerning the gas content in the defined

245 groups. Then, for each group, a Pearson correlation coefficient analysis was

246 carried out (Kendall and Stuart 1973), which allowed us to determine different

247 relationships between variables pairs. The most significant variables from this

248 independent study were compared statistically with each petrographic variable.

249 Finally, the stepwise multiple regression method was applied, in which the

250 contribution of each predictor variable to the response variable was analyzed. The

251 algorithm determines which are the most important predictor variables for each

252 one of the analyzed wells.

253

\section{Results and discussion}

\section{Gas content}

256 The ash-free gas total content results (Ortíz et al. 2016) in the twenty-five coal 257 seams analyzed ranges between 37.54- 818.14 SCF /ton. The lowest value 258 corresponds to M-15 from the Landázuri 2 well and the highest value measured at 259 M-3 from the Landázuri 1 well.

261 Petrographic analysis

262 To the southeast of the De Armas syncline (see Fig. 1), the average reflectance of 263 the Vitrinite ranges between 1.22- 1.86\% MVB-LVB for Landázuri 1. The 264 measured gas content fluctuates between 80.66 -818.14 SCF/ton, where 78.90-

$26591 \%$ of the values obtained correspond to methane gas. To the northwest of the 266 structure, coals are classified as HVBA- MVB for Landázuri 2 with values 267 between 0.9 and $1.26 \%$ reflectance. The measured gas content is in the range 
$37.54-484.88 \mathrm{SCF} /$ ton, where $41.90-92.50 \%$ of the obtained values correspond to

269 methane gas (Ortiz et al. 2016; see Tables 1 and 2).

After having undergone the desorption process, the macerals showed numerous empty spaces of irregular size and shape. As shown in Tables 1 and 2, the Vitrinite content ranges between $65.71 \%$ and $94.03 \%$ in the analyzed samples.

274 Likewise, the highest values correspond to the subgroup Detrovitrinite 275 (Colodetrinite, Vitrodetrinite) and Gelovitrinite (Gelinite Colodetrinite involves 276 different macerals such as Inertodetrinite and is observed partially fusinitized and 277 devolatized (Fig. 5c, 5f, 5k, 51, 5n, 6c, 6f, 6h). Gelinite is of a homogeneous 278 aspect and is occasionally fractured (Fig. 5e, 6d), Vitrodetrinite is observed as 279 angular fragments and is concentrated in the edges of the Vitrinite macerals (Fig. $2805 \mathrm{j}, 6 \mathrm{e})$.

The macerals content of the Inertinite group varies between $5.97-34.07 \%$ in the analyzed coal seams. Inertodetrinite is the most abundant maceral and is observed contained in Colodetrinite mainly (Fig. 5f, 5m, 6f, 6i). Fusinite and Semifusinite were quantified as preserved macerals-preserved cell structure and degraded-no cell structure (Fig. 5e, 5m, 54n, 5o, 6h, 6k). The macerals empty spaces may be empty or with mineral matter filling (Fig. 5e, 5g, 5i, 5b, 6g, 6h, 6j, 6k). The Liptinite content is very low or zero, and therefore, the maceral group was not analyzed.

The mineral matter comprises clay filling, replacing macerals (Fig. 5a, 5d, 6a, 6c)

292 and pyrite, with values between 3.60 to $30.00 \%$, obtaining the highest values for 293 Landázuri-1 (see Tables 1 and 2). In the coal seams analyzed, the pyrite was 294 characterized according to morphology into framboidal, granular, massive, and 295 crystalline. It was observed replacing macerals and filling voids and fractures 296 (Fig. 5b, 5g, 5h, 5i, 6b, 6j).

298 Correlations between macerals of Vitrinite and Inertinite groups, and the 299 petrographic indexes (GI, TPI, VI, GWI, and Vitrinite- VI radius) are listed in $300 \quad$ Tables 3 and 4. 


\section{Group selection}

303 The Elbow plots shown in Figures $8 \mathrm{~A}$ and $\mathrm{B}$ allows us to discriminate seams 304 groups for each well. Three seams' groups from the Landázuri 1 well show that 305 the quadratic distance between the elements that comprise them is less than 306 20,000. While Landázuri 2 well has a distance between two and three seams' 307 groups in the range between 30,000 and 50,000. Although, for both wells with 4 308 and 5 groups, the distance is minimized the samples number within each was 309 taken into account. The Landázuri 1 well consists of fourteen core samples, while 310 the Landázuri 2 well comprises 11 samples. Accepting groups of 4 or 5 would 311 imply that they would be formed by 1 or 2 samples and, in that case, the 312 correlations between the variables would not make any geological sense, since 313 any straight line could be adjusted by linear regression of two measurements. 314 Thus, we decided to keep the 3 groups for Landázuri 1 and 2 groups for Landázuri 3152 (Fig. 7). The dendograms produced using PCA (Principal Component Analysis) 316 analysis suggest that the samples integrate each group according to the measured 317 gas content (Fig. 8).

\section{Linear regression analysis}

Relationship between measured gas volume and Vitrinite Reflectance

321 The coal rank has been defined as an important factor in the maceral composition 322 variation and, therefore, in the gas storage capacity (e.g., Crosdale et al. 1998, 323 2017; Keshavarz 2017). Other authors deduced that a higher coal rank indicates a 324 greater depth, and as the Vitrinite percentage increases the gas content is higher 325 (Bustin and Clarkson 1998, among others). In the Landázuri coals, the reflectance 326 analysis reveals that the gas content does not increase proportionally with rank, 327 nor with depth, taking into account that the highest reflectance values are not 328 found in the lowest stratigraphic position (see Fig. 9 a,c).

329 It is evident that the middle-to-high range coals- (MVB- LVB) from the Landázuri

3301 well, duplicate in gas content the lower-range coals (HVB - MVB) from the 331 Landázuri 2 well. The gas content $(<600$ SCF / ton- Landázuri 1 and $<300$ 332 Landázuri 2) have no relationship with Vitrinite Reflectance, while the groups 
333 with higher gas content present a correlation factor R2 $=0.74$ for Landázuri 1 and 3340.99 for Landázuri 2 (Fig. 9 b, d).

337 The relationship between the Vitrinite percentage and the gas content indicates as

338 the Vitrinite content increases, the gas adsorption capacity decreases, showing a 339 negative slope in the correlation graph (Hackley et al. 2000; Mares and Moore 340 2008). The above applies to the groups defined with the higher measured gas 341 content ( $>600$ - Landázuri 1 and $>300$ - Landázuri 2). The other groups show a 342 positive correlation, which indicates that as the percentage of Vitrinite the 343 measured gas content also increases. The coal rank inclusion suggests that the 344 Vitrinite content does not influence gas adsorption in the BMV-BBV rank coals 345 (Laxminarayana and Crosdale 1999). That is the case for the Landázuri coals, 346 with $>600 \mathrm{SCF} /$ ton and $>300 \mathrm{SCF} /$ ton gas content, the opposing relationship 347 occurs in lower gas content coals. (see Fig. $10 \mathrm{a}, \mathrm{b}$ ).

349 The dependence between structured (Telovitrinite, Gelovitrinite), and degraded 350 (Detrovitrinite) macerals defines the Vitrinite radius. Fig. 10 shows the correlation 351 with positive character in the medium to high-rank Landázuri 1 coals with a gas 352 content measured between 200-800 SCF/ton. The VR is irrelevant in $<200 \mathrm{SCF} /$ 353 ton gas content coals because of its zero tendency. The coals of the Landázuri 2 354 well have a positive correlation with the gas content reflecting the Vitrinite 355 structured macerals importance. (See Fig. 10 c, d; Tables 3 and 4).

358 The correlation of the Inertinite percentage with the gas content suggests a 359 positive influence in the groups with higher gas content ( $>600$ and $>300 \mathrm{SCF} / \mathrm{ton})$.

360 The remaining groups indicate a correlation with a negative trend. (See Fig. 11; 361 Table 1 to 4$)$.

362 The IR has merit in the defined coals groups, specifically in the $>600 \mathrm{SCF} /$ ton gas 363 content -Landázuri 1, where the degraded Inertinite is higher than the structured 364 Inertinite. (See Fig. 11a, b; Table 1 to 4). 
366 The Inertinite cellular structure is an important factor in methane gas enrichment

367 in the defined groups with higher gas content. It is contrary to what was observed

368 with the percentage of Vitrinite with a high degree of metamorphism that does not

369 allow filling the pores with gas. (e.g., Mares and Moore 2008; Wang 2018).

370 Although an inverse relationship of the Inertinite radius is observed in the $>600$

$371 \mathrm{SCF} /$ ton group, the pore size distribution and its role in the gas desorption process

372 in both structured and the degraded inerts remain significant (see Fig. 11c, d).

\section{Relationship between the measured gas content and the mineral matter}

375 percentage

376 The relationships between the mineral matter content with the measured gas

377 content do not show correlation or tend to zero, except in the group $<300 \mathrm{SCF} / \mathrm{ton}$

378 in Landázuri 2 (see Fig. 12). The pyrite is observed as euhedral and anhedral,

379 framboidal grains or crystals, filling pores and voids, as an indicator of a

380 syngenetic process (Raharjo 2018; Dai et al. 2020). The early syngenetic and

381 diagenetic origin is related to a higher gas content in the coals of Landázuri 1.

382 According to Bertrand (1989), this condition is due to the contribution of the

383 microporosity of the mineral matter after the gelation process. The different forms

384 of pyrite concentration are shown in Fig. 13. We discriminated that epigenetic

385 pyrite concerns intermediate to low gas contents as occurs in coal seams: M17 and

386 M2 in Landázuri 2, this reduction in methane gas sorption, according to Raharjo

387 (2018) could be due to the large size and area covered by pyrite, which, according

388 to Laxminarayana (1999), and Warwick et al. (2008) reduce gas sorption by a

389 retention process.

Relationship between measured gas content and the coal facies

392 The calculated indices were: TPI- Tissue Preservation Index, GI- Gelation Index,

393 VI- Vegetation Index, GWI- Groundwater Index, and V/I radius. They are the

394 water table variations concerning organic matter preservation and are calculated

395 as follows: 


$$
\text { TPI }=\text { Telinite }+ \text { Colotelinite }+ \text { Semifusinite }+ \text { Fusinite } / \text { Colodetrinte }+ \text { Macrinite }
$$

$$
\begin{gathered}
\text { VI }=\text { Colotelinite }+ \text { Fusinite }+ \text { Semifusinite }+ \text { Suberinite }+ \text { Resinite } / \text { Colodetrinite } \\
+ \text { Inertodetrinite }+ \text { Alginite }+ \text { Liptodetrinite }+ \text { Sporinite }+ \text { Cutinite }
\end{gathered}
$$

405 The index that reveals the degree of persistence of wet and dry conditions is the 406 GI (see Fig. 14e, f); and the GWI and the Vitrinite/Inertinite ratio (V/I) represent 407 the degree of gelation of the fabrics according to the water and $\mathrm{pH}$ contributions 408 (see Fig. 14c, d, i, j). These indices show the same behavior as the percentage of 409 Vitrinite concerning the gas content illustrated in Fig. 10a, b. The GI value 410 exception is the Landázuri 2 well with $>300 \mathrm{SCF} /$ ton content, with a very low 411 Telovitrinite and Colodetrinite content; therefore, the index acquires a high value.

412 On the other hand, the TPI index as an indicator of the degree of humification of 413 organic matter macerals (see Fig. 14a, b) and the VI index (see Fig. 14g, h) show 414 the contrast of macerals of forest affinity with herbaceous marginal, indicating the 415 same trend as that of the VR in Fig. 10c, d.

417 The Calder et al. (1991) and Diessel (1986) models indicate that the organic 418 matter in Landázuri was transformed in a limnic environment (marshy or 419 lacustrine continental basins) that fulfills the Vitrinite> Inertinite and Degraded 420 Vitrinite> Structured Vitrinite condition (Fig. 15 and 16). The coal facies 421 variation is not evident in the same geological formation, as the seams are from 422 the same well.

\section{Pearson's analysis}

424 The relationships between pairs of variables are plotted as Pearson correlograms, 425 these summarized the linear regression analysis, highlighting the inertinitic 426 macerals contribution in the group of each well with higher desorbed gas content 427 and of Vitrinite $(\mathrm{V})$ and $\mathrm{V} / \mathrm{I}$ radius in the coals categorized with medium to low 
428 gas content (see Fig. 17). For these correlograms, only variables that have a 429 relationship were plotted using a p-value of 0.25 . Additionally, the correlograms

430 allow us to corroborate other linear relationships between variables that had not 431 been considered before and to identify their influence on the response variable, as 432 is the case of gas content.

\section{Multiple regression analysis}

435 The analysis was performed considering the variable Gas V (Gas Volume) as the 436 response variable and the variables: Ro, StrV, StrI, Gas V, \%V, and \%I as the 437 predictor variables.

439 In Tables 5 and 6 , a summary of the multiple linear regression statistics is 440 presented for the initial and final models of the Landazuri-1 well. According to 441 the Table 5 none of the five predictor variables (Ro, Str I, Str V, \%V and \%I) 442 would be significant in the calculation of gas volume. The closest is Str V with a 443 probability of 0.133 . The adjusted regression coefficient is 0.05362 and $p$-value $=$ 444 0.3984. Once the stepwise selection procedure is applied, Table 6 shows that the 445 Str V variable is significant assuming a reliability level of 99\%, the adjusted R2= 4460.229 increases, while the p-value diminishes to 0.08328 , which imply that the 447 two predictors' variables Str I and Str V are significant to reproduce the gas 448 volume.

449 Considering the same five predictor variables previously mentioned, in Table 7 450 we summarized the multiple linear regression results for the Landazuri-2 well. 451 According to this Table, only Str V is a significant variable with a probability of 4520.0998 for the gas volume estimation. However, Ro and Str I are other variables 453 that could have a significant effect on gas volume, with probabilities of 0.2411 454 and 0.2235 , respectively. After the application of the stepwise method adjusted R2 455 correlation coefficient shows an improvement with respect to the initial model, 456 evolving from 0.6991 to 0.7508 . Similarly, the p-value of the initial model 457 improves from 0.04023 to 0.004795 in the final model. Thus, Ro, Str I, and Str V 458 represent significant predictors assuming a confidence level of 99\%. (see Table 8).

459 Fig. 18 shows in blue those predictor variables that have a positive influence with 460 the gas content. The analysis highlights the Reflectance Vitrinite importance and 
461 the structured macerals content in the coal seams related to the gas content, which

462 is a consequence of the coal formation history.

\section{Conclusions}

465 The measured gas volumes (SCF/ton) in the rank HVBA- MVB Landázuri 2 coals

466 fluctuate between 37.54 to 484.8, while rank MVB- LVB Landázuri 1 coals

467 doubles it, reaching values of $818.14 \mathrm{SCF} / \mathrm{ton}$. The definition of the groups

468 according to the measured gas content allows highlighting the relationship of the

469 maceral composition with the pore size (micropore, macropore, mesopore), and 470 the coal rank.

472 The petrographic variables analyzed to reveal that the groups with the highest gas 473 content (> $600 \mathrm{SCF} /$ ton- MVB, LVB-Landázuri 1;> $300 \mathrm{SCF} /$ ton- HVBA, 474 MVB-Landázuri 2) exhibit higher content of inertinite (macropore, mesopore), 475 while the medium to low gas content is directly related to the content of vitrinite 476 (micropore) emphasizing structured macerals (see Fig. 19).

478 Further, mineral matter contributes microporosity about gas content showing 479 positive correlation except in coals $>300 \mathrm{SCF} /$ ton from Landázuri 2. The pyrite 480 syngenetic and early diagenetic is related to higher gas content, while epigenetic 481 pyrite concentration covers the greater surface area and is related to intermediate 482 to low measured gas contents.

483

484 The maceral relationship in the definition of the petrographic indices reveals 485 limnic facies of continental swampy or lacustrine basins. The GI, GWI, and V/I 486 indices present the same behavior as the Vitrinite content in each group analyzed, 487 except for the high GI value in the group with $>300$ in Landázuri 2 well, as the 488 result of the low Telovitrinite and Colodetrinite content. The TPI and VI indices 489 are equivalent to the Vitrinite radius. 
The authors would like to thank the geological engineers Claudia Duarte, Luis Fernando Ortiz,

493 Fernando Andres Parra of the Energetics Group - Servicio Geológico Colombiano, for the detailed

494 field work, drilling and desorption analysis of the coal seams; the group of professionals of the

495 Laboratory of Characterization, Processing and Research of Coal and Energetic Materials -

496 Servicio Geológico Colombiano, for the reflectance analysis of the selected samples. Mauricio

497 Bermúdez thanks the UPTC SGI-DIN-3104 Project.

\section{Declarations}

501 Funding This research is part of the Exploration in Energy Resources Project of

502 the Servicio Geológico Colombiano.

Availability of data and materials Applicable.

Conflict of interest: The authors have no conflicts of interest to declare that are relevant to the content of this article.

References

ASTM. (2005). D2799-05 "Standard test method for microscopical determination of the maceral composition of coal" ASTM Philadelphia ASTM (2005b) D2798-05 Standard test method for microscopical determination of the vitrinite reflectance of coal. ASTM Philadelphia

Bertrand, P. R. (1989). Microfacies and petroleum properties of coals as revealed by a study of

518 North Sea Jurassic coals. 13, 575-595.

Blandón, A. (2007). Contribución de la materia orgánica sedimentaria a la determinación del paleoambiente y del potencial de generación de hidrocarburos en los carbones de la Formación Amagá (Colombia). These de doctorat: Univ. Genève 2006 no. Sc. 3806

BP (2021) BP statistical review of world energy 2020 70th edition. BP plc London. https://www.bp.com/content/dam/bp/business-sites/en/global/corporate/pdfs/energyeconomics/statistical-review/bp-stats-review-2021-full-report.pdf

Busch, A., \& Gensterblum, Y. (2011). CBM and CO2-ECBM related sorption processes in coal: A review. International Journal of Coal Geology, 87(2), 49-71. https://doi.org/10.1016/j.coal.2011.04.011 
Busch, A., Han, F., y Magill, C. R. (2019). Paleofloral dependence of coal methane sorption capacity. International Journal of Coal Geology, 211(June). https://doi.org/10.1016/j.coal.2019.103232

536 Bustin, A. M. M., y Bustin, R. M. (2016). Total gas-in-place, gas composition and reservoir properties of coal of the Mannville coal measures, Central Alberta. International Journal of Coal Geology, 153, 127-143. https://doi.org/10.1016/j.coal.2015.11.011 capacity and gas content. International Journal of Coal Geology, 38(1-2), 3-26. https://doi.org/10.1016/S0166-5162(98)00030-5

544 Calder, J. H., Gibling, M. R., y Mukhopadhyay, P. K. (1991). Peat formation in a Westphalian B 545 piedmont setting, Cumberland Basin, Nova Scotia: implications for the maceral-based 546 interpretation of rheotrophic and raised paleomires. Bulletin - Societe Geologique de France, 547 162(2), 283-298.

549 Cardott, B. J., y Curtis, M. E. (2018). Identification and nanoporosity of macerals in coal by 550 scanning electron microscopy. International Journal of Coal Geology, 190(February 2017), 205217. https://doi.org/10.1016/j.coal.2017.07.003

553 Castaño, L; Gómez, O. (2001). Caracterización, origen, evolución y potencial de utilización de los 554 carbones de la Secuencia

555 Volcanoclástica de Aranzazu Caldas. Universidad de Caldas, Thesis

Chalmers, G. R. L., y Marc Bustin, R. (2007). On the effects of petrographic composition on coalbed methane sorption. International Journal of Coal Geology, 69(4), 288-304.

561 Crosdale, P. J., Beamish, B. B., y Valix, M. (1998). Coalbed methane sorption related to coal

562 composition. International Journal of Coal Geology, 35(1-4), 147-158.

563 https://doi.org/10.1016/S0166-5162(97)00015-3

565 Crosdale, P. J. (2017). Coal bed methane. Geology: current and future developments. Eds. Suárez-

566 Ruíz, I., Mendonça, João. Vol 1. 258-286

568 Dai S, Bechtel A, Eble CF et al (2020) Recognition of peat depositional environments in coal: a 569 review. Int J Coal Geol

$570 \quad$ 219:103383. https://doi.org/10.1016/j.coal.2019.103383 
572 Diessel CFK. (1986). On the correlation between coal facies and depositional environments.

573 Proceeding of 20th symposium Department of Geology. University Newcastle NSW, 19-22

Etayo-Serna, Fernando. 2019. "Basin development and tectonic history of the Middle Magdalena Valley”. En Estudios geológicos y paleontológicos sobre el Cretácico en la región del embalse del río Sogamoso, Valle Medio del Magdalena, dirección científica y edición de Fernando Etayo-

578 Serna. Compilación de los Estudios Geológicos Oficiales en Colombia vol. XXIII. Bogotá:

579 Servicio Geológico Colombiano.

Gómez, L.A., Patiño, A., Renzoni, G., Beltrán, A., Quintero, C. y Manrique, M. (2008).

582 Cartografía geológica y muestreo geoquímico escala 1:100 000 de la plancha 119 Barrancabermeja VMM. INGEOMINAS y GRP Ltda. Bogotá.

Gómez, J. S., López, M. D., 2017. Paleoenvironments of coals using organic petrography and their relationship with physicochemical properties, Guaduas Formation, Checua-Lenguazaque syncline. Tesis de grado- UPTC- Colciencias, Tunja

589 Guatame C, Sarmiento Perez G (2004) Interpretación del Ambiente Sedimentario de los Carbones de la Formación Guaduas en el Sinclinal Checua-Lenguazaque a partir del análisis petrográfico. Geología Colombiana 29:41-58

Guatame, C., \& Rincón, M. (2021). Coal petrology analysis and implications in depositional environments from upper Cretaceous to Miocene: a study case in the Eastern Cordillera of Colombia. International Journal of Coal Science and Technology. https://doi.org/10.1007/s40789020-00396-Z

Guo Q, Littke R., Zieger, L. (2018). Petrographical and geochemical characterization of subbituminous coals from mines in the Cesar-Ranchería Basin, Colombia. Int J Coal Geol 191:66-79. https://doi.org/10.1016/j.coal.2018.03.008 Hackley, P. C., Warwick, P. D., \& Breland, F. C. (2007). Organic petrology and coalbed gas content, Wilcox Group (Paleocene-Eocene), northern Louisiana. International Journal of Coal Geology, 71(1 SPEC. ISS.), 54-71. https://doi.org/10.1016/j.coal.2006.05.009 $100-108$

608 Hou, H., Shao, L., Li, Y., Li, Z., Wang, S., Zhang, W., y Wang, X. (2017). Influence of coal 609 petrology on methane adsorption capacity of the Middle Jurassic coal in the Yuqia Coalfield, 610 northern Qaidam Basin, China. Journal of Petroleum Science and Engineering, 149(February), 611 218-227. https://doi.org/10.1016/j.petrol.2016.10.026 
615 ICCP. (1998). The new vitrinite classification (ICCP System 1994) Fuel, 77, 349-358

617 ICCP. (2001). The new inertinite classification (ICCP System 1994). Fuel, 80, 459-471

618 ISO (2014). 17892-2. Geotechnical investigation and testing — Laboratory testing of soil — Part

619 2: Determination of bulk density

620 adsorption of low-rank coal in China. Journal of Natural Gas Science and Engineering, 27, 207218. https://doi.org/10.1016/j.jngse.2015.08.052

Kalkreuth, W. D., Marchioni, D. L., Calder, J. H., Lamberson, M. N., Naylor, R. D., \& Paul, J. (1991). The relationship between coal petrography and depositional environments from selected coal basins in Canada. International Journal of Coal Geology, 19(1-4), 21-76. https://doi.org/10.1016/0166-5162(91)90014-A

Kendall, M. G., Stuart, A., 1973. The Advanced Theory of Statistics, Volume 2: Inference and Relationship, Griffin. ISBN 0-85264-215-6

633 Keshavarz, A., Sakurovs, R., Grigore, M., \& Sayyafzadeh, M. (2017). Effect of maceral

634 composition and coal rank on gas diffusion in Australian coals. International Journal of Coal

635 Geology, 173, 65-75. https://doi.org/10.1016/j.coal.2017.02.005

637 Lamberson, M. N., y Bustin, R. M. (1993). Coalbed methane characteristics of Gates Formation

638 coals, northeastern British Columbia: effect of maceral composition. In American Association of

639 Petroleum Geologists Bulletin (Vol. 77, Issue 12, pp. 2062-2076).

640 https://doi.org/10.1306/bdff8fd8-1718-11d7-8645000102c1865d

641

642 Laxminarayana, C., y Crosdale, P. J. (1999). Role of coal type and rank on methane sorption

643 characteristics of Bowen Basin, Australia coals. International Journal of Coal Geology, 40(4),

644 309-325. https://doi.org/10.1016/S0166-5162(99)00005-1

645

646 Li, X., Fu, X., Liu, A., An, H., Wang, G., Yang, X., Wang, L., \& Wang, H. (2016). Methane

647 Adsorption Characteristics and Adsorbed Gas Content of Low-Rank Coal in China. Energy and

648 Fuels, 30(5), 3840-3848. https://doi.org/10.1021/acs.energyfuels.6b00071

650 Lloyd, S., 1982. "Least Squares Quantization in Pcm.” IEEE Transactions on Information Theory $65128(2): 129-37$ 

properties of the coal reservoirs in Western Guizhou and Eastern Yunnan, China. International Journal of Oil, Gas and Coal Technology, 8(2), 221-234. https://doi.org/10.1504/IJOGCT.2014.064837

658 Li, Y., Cao, D., Wu, P., Niu, X., y Zhang, Y. (2017). Variation in maceral composition and gas content with vitrinite reflectance in bituminous coal of the eastern Ordos basin, China. Journal of

663 Mares, T. E., y Moore, T. A. (2008). The influence of macroscopic texture on biogenically-derived 664 coalbed methane, Huntly coalfield, New Zealand. International Journal of Coal Geology, 76(1-2),

665 175-185. https://doi.org/10.1016/j.coal.2008.05.013

666 Mariño-Martínez, J. E., \& Mojica-Amaya, A. (2014). Relación entre la petrografía del carbón y el 667 contenido de gases en la cuenca de Amagá (Antioquia, Colombia). Revista Facultad De Ingeniería, 668 23(37), 33. https://doi.org/10.19053/01211129.2788

670 Mariño, J.E., Castro-Rodríguez, A., Botero, .A, Mojica, L., Granados, D., Acuña, C. (2015). GAS ASOCIADO AL CARBÓN (CBM o GMAC), Geología, contenidos, reservas, mineria y posibilidades en Colombia. ISBN: 978-958-660-212-9

Mastalerz, M., y Drobniak, A. (2020). Coalbed methane: Reserves, production, and future outlook.

675 In Future Energy: Improved, Sustainable and Clean Options for Our Planet. Elsevier Ltd. https://doi.org/10.1016/B978-0-08-102886-5.00005-0

MONROY, W., SANDOVAL, M. 2014. Exploración y Evaluación de carbones en el Área

682 Cimitarra Sur y sur del Área Río Opón-Landázuri del Departamento de Santander. Servicio 683 Geológico Colombiano. Bogotá.

688 Ortiz, L., Parra, F., Duarte., y Rincón, M. (2016). Exploración gas metano asociado al carbón.

689 Área Landázuri - Velez. Departamento de Santander. Bogotá: Servicio Geológico Colombiano 

the capacity of gas methane absorption in coal formation Tanjung Barito in Binuang Region,

696 South Kalimantan. IOP Conference Series: Earth and Environmental Science, 212(1). https://doi.org/10.1088/1755-1315/212/1/012029

698 Sarmiento, G., Puentes, J., \& Sierra, C. (2015). Evolución geológica y estratigrafía del sector norte

699 del Valle Medio del Magdalena. Geologia Norandina, 12, 51-83.

700 http://sociedadcolombianadegeologia.org/wp-content/uploads/2017/06/Norandina_No.12_Art4.pdf

Schwarz, G., 1978, Estimating the Dimension of a Model: Annals of Statistics, v. 6, p. 461-464.

Singh, A. K. (2016). Petrographic characterization and evolution of the Karharbari coals, Talcher

705 Coalfield, Orissa, India. International Journal of Coal Science and Technology, 3(2), 133-147.

706 https://doi.org/10.1007/s40789-016-0132-3

707 Suárez-Ruiz, I., Flores, D., Mendonça Filho, J. G., \& Hackley, P. C. (2012). Review and update of 708 the applications of organic petrology: Part 1, geological applications. International Journal of Coal

709 Geology, 99, 54-112. https://doi.org/10.1016/j.coal.2012.02.004

Terraza Melo, Roberto. 2019. “Formación La Luna’: expresión espuria en la geología 712 colombiana”. En Estudios geológicos y paleontológicos sobre el Cretácico en la region del 713 embalse del río Sogamoso, Valle Medio del Magdalena, dirección científica y edición de Fernando 714 Etayo-Serna. Compilación de los Estudios Geológicos Oficiales en Colombia vol. XXIII. Bogotá:

715 Servicio Geológico Colombiano

Wang, K., Fu, X., Qin, Y., y Sesay, S. K. (2011). Adsorption characteristics of lignite in China. Journal of Earth Science, 22(3), 371-376. https://doi.org/10.1007/s12583-011-0189-2

Wang, M. S., Zou, G. G., y Zhu, R. B. (2018). Relationship between Maceral of Coal and Coalbed Methane adsorption ability in Sihe Coalmine of Qinshui Basin, China. IOP Conference Series:

724 Warwick, P. D., Breland, F. C., \& Hackley, P. C. (2008). Biogenic origin of coalbed gas in the 725 northern Gulf of Mexico Coastal Plain, U.S.A. International Journal of Coal Geology, 76(1-2),

726 119-137. https://doi.org/10.1016/j.coal.2008.05.009

\section{FIGURES CAPTIONS}

729 Fig. 1 Geological map of the Landázuri- Vélez area- Middle Magdalena Valley Basin. Source: $730 \quad$ (Ortíz et al. 2016) 
732 Fig. 2 Generalized stratigraphic column of the Upper Cretaceous- Middle Magdalena Valley Basin

733 and Coal seams distribution from Landázuri 1 and 2 wells. Source: (Ortíz et al. 2016; Etayo-Serna 734 2019)

735 Fig. 3 Gas desorption curve (Ortíz et al. 2016)

737 Fig. 4 Ash-free gas content (SCF/ton) of coal seams from Landázuri 1 and Landázuri 2 wells 738 (Ortíz et al. 2016)

Fig. 5 Coal seams photomicrographs of the Landázuri 1 well after desorption gas process. a. Clay 741 filling inert's empty spaces -M23, b. Framboidal pyrite -M21, c. Devolatized Colodetrinite -M20,

742 d. Clay mineral matter -M17, e. Fractured Vitrinite and structured Fusinite -M14, f. Inertodetrinite 743 in devolatized Colodetrinite -M13, g. Framboidal pyrite in Semifusinite -M12, h. Mineral matter 744 M11, i. Pyrite -M10, j. Vitrodetrinite, k. Colodetrinite -M7, 1. Devolatized Vitrinite -M6, m. 745 Preserved Fusinite and Inertodetrinite- M5, n. Vitrinite and inerts after desorption -M4, o. 746 Degraded inerts - M3

Fig. 6 Coal seams photomicrographs of the Landázuri 2 well after desorption gas process. a. Clay 749 minerals -M18, b. Pyrite filling Inertinite's spaces -M17, c. Devolatilized Vitrinite - M16, d. Clay 750 minerals in fractured Vitrinite -M15, e. Colotelinite and Vitrodetrinite -M14, f. Inert in 751 Colodetrinite -M11, g. Semifusinite's spaces filled with mineral matter -M10, h. Empty spaces in 752 Colodetrinite and Semifusinite - M9, i. Inertodetrinite in Colodetrinite -M5, j. Pyrite in Fusinite 753 M3, k. Fusinite -M2

755 Fig. 7 Elbow-plots for (A) Landázuri 1and (B) Landázuri 2 wells

757 Fig. 8 Dendograms showing results of cluster analysis (A) Landázuri-1 (B) Landázuri-2 wells

759 Fig. 9 Coal rank (Ro) relation with depth and gas content measured (\%Ro) (a, c) Landázuri-1 well. $760 \quad(b, d)$ Landázuri-2 well

761 HVBA- High Volatile Bituminous A, MVB- Medium Volatile Bituminous, - LVB Low Volatile 762 Bituminous.

764 Fig. 10 Relationship between Vitrinite percentage (fmmb) and the Vitrinite Radius with the gas 765 content (SCF/ton) (a, c) Landázuri-1 well, $(b, d)$ Landázuri-2 well 
Fig. 11 Relationship between Inertinite content (fmmb) and the Inertinite Radius with the gas content (scf/ton) (a, c) Landázuri-1 well, (b, d) Landázuri-2 well

Fig. 12 Relationship between mineral matter and the gas content (SCF/ton) (A). Landázuri 1 (B)

Fig. 13 Microphotographs a. Clay minerals in M5- Landázuri-1, b. Clay minerals and pyrite -M17-

774 Landázuri-2, c. Clay and others -M21- Landázuri-1, d. Framboidal pyrite -M17- Landázuri-2, e. 775 Framboidal pyrite -M17-Landázuri-2, f. Framboidal pyrite -M7-Landázuri-1, g. Framboidal pyrite 776 -M7-Landázuri-2, h. Syngenetic-diagenetic pyrite -M3-Landázuri-2, i. Epigenetic pyrite -M17777 Landázuri-2, j. Epigenetic pyrite -M2-Landázuri-2, k. Epigenetic pyrite -M17-Landázuri-2, 1. 778 Syngenetic framboidal pyrite -M16-Landázuri-2, m. Diagenetic pyrite -M17-Landázuri-1, n. 779 Diagenetic pyrite -M4-Landázuri-1, o. Diagenetic pyrite -M10-Landázuri-1, p. Late diagenetic 780 pyrite?-M17-Landázuri-2

781 Fig. 14 Relationships between gas content (SCF/ton) and petrographic indexes (TPI, GWI, GI, VI, 782 and $\mathrm{V} / \mathrm{I})$

784 Fig. 15 Coal facies (GI, TPI) Source: Diessel (1986) and modified by Kalkreuth et al. 1991. a. 785 Landázuri 1. b. Landázuri 2 A. Vitrinite> Inertinite, Degraded Vitrinite $>$ Structured Vitrinite B. 786 Vitrinite $>$ Structured Inertinite, Vitrinite $>$ Degraded Vitrinite C. Inertinite $>$ Vitrinite 787 Inertodetrinite $>$ Semifusinite- Fusinite D. Inertinite $>$ Vitrinite Semifusinite+Fusinite $>$ 788 Inertodetrinite

792 Fig. 17 Pearson correlograms showing relationships between pairs of variables for Landázuri 1 793 and Landázuri-2

794 Ro- Average Vitrinite Reflectance, V fmmb - Vitrinite free mineral matter, I fmmb- Inertinite free 795 mineral matter, mm- mineral matter, V/I- Vitrinite/Inertinite radius, Deg V- Degraded Vitrinite, 796 Str I - Structured Inertinite, Deg I - Degraded Inertinite, Str V- Structured Vitrinite, RV- Vitrinite 797 Radius, IR- Inertinite Radius, Gas V- Total gas volume measured SCF/ton

799 Fig. 18 Behavior analysis of predictor variables (Str V, Str I, \%V, \%I, Ro) versus response 800 variable (Gas V) for the wells: a. Landazuri 1 and b. Landazuri 2

802 Fig. 19 Synthesis of the importance of maceral groups and reflectance for the measured gas 803 content 


\section{TABLES CAPTIONS}

805 Table 1. Mean Vitrinite reflectance, measured gas volume, and maceral composition of the coal 806 seams - Landázuri 1 well

807 Table 2. Mean Vitrinite reflectance, measured gas volume, and maceral composition of the coal 808 seams- Landázuri 2 well

809

810 Table 3. Relationships between maceral content and petrographic indexes for coal seams of the 811 Landázuri 1 well

812

813 Table 4. Relationships between maceral content and petrographic indexes for coal seams of the 814 Landázuri 2 well

815 Table 5. Summary of multiple linear regression for initial model of the Landazuri-1 well 816

817 Table 6. Summary of multiple linear regression for final model of the Landazuri-1 well 818

819 Table 7. Summary of multiple linear regression for initial models of the Landazuri-2 well 820

821 Table 8. Summary of multiple linear regression for final model of the Landazuri-2 well 
Figures

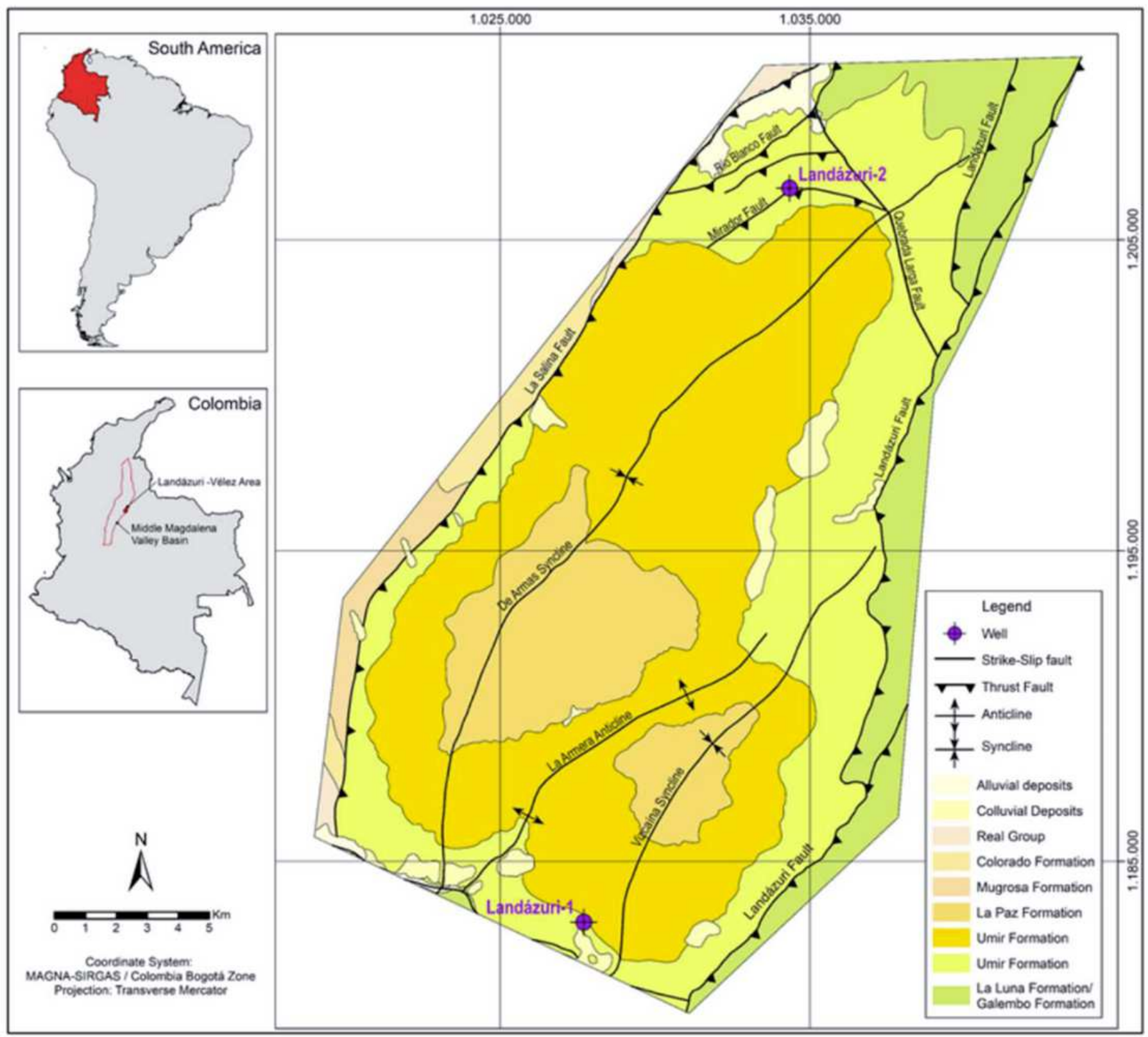

Figure 1

Geological map of the Landázuri- Vélez area- Middle Magdalena Valley Basin. Source: (Ortíz et al., 2016) 


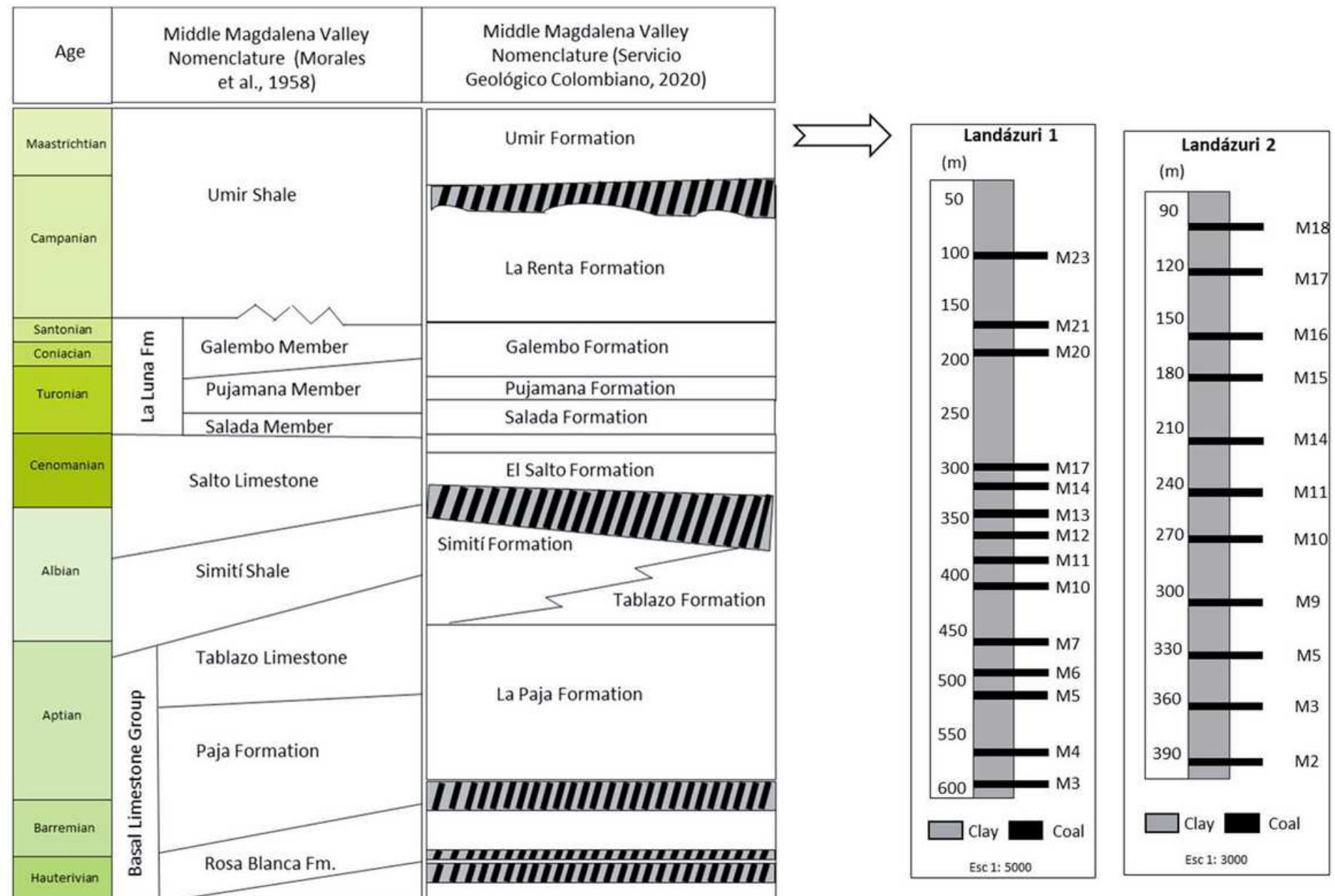

\section{Figure 2}

Generalized stratigraphic column of the Upper Cretaceous- Middle Magdalena Valley Basin and Coal seams distribution from Landázuri 1 and 2 wells. Source: (Ortíz et al., 2016; Etayo-Serna, 2019) 


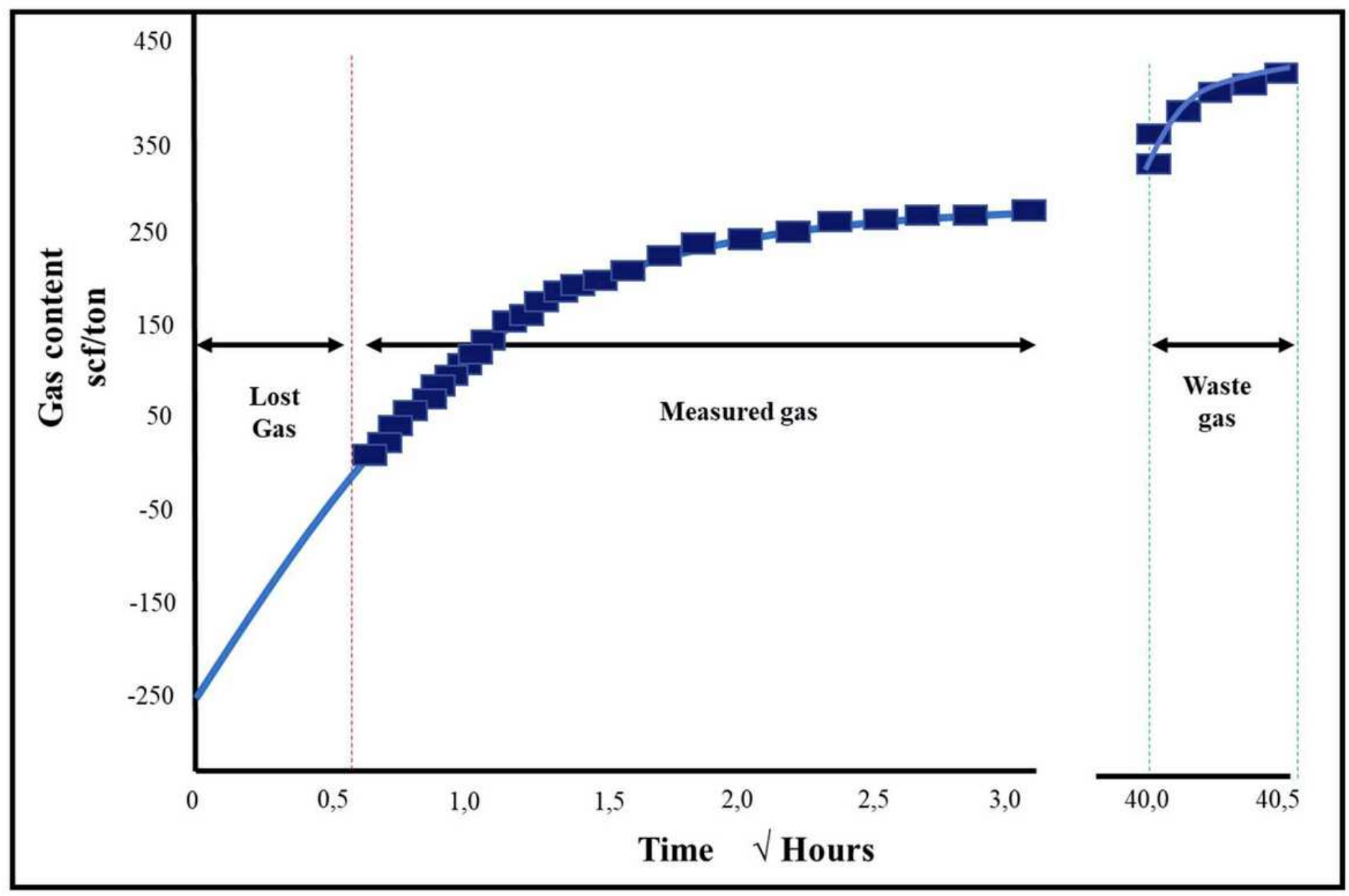

Figure 3

Gas desorption curve (Ortíz et al., 2016) 

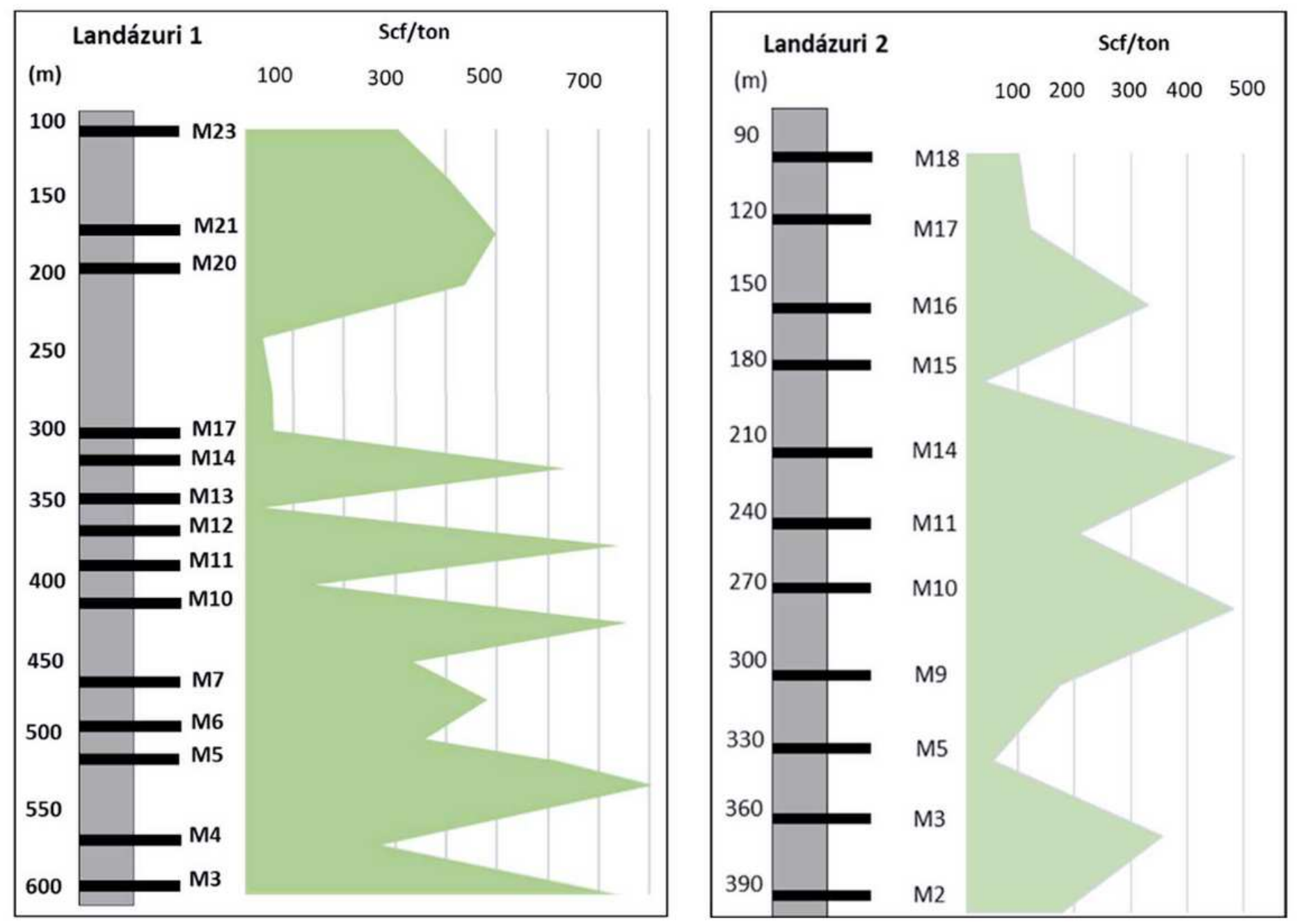

Figure 4

Ash-free gas content (SCF/ton) of coal seams from Landázuri 1 and Landázuri 2 wells (Ortíz et al., 2016) A

\section{Figure 5}

Coal seams photomicrographs of the Landázuri 1 well after desorption gas process. a. Clay filling inert's empty spaces -M23, b. Framboidal pyrite -M21, c. Devolatized Colodetrinite -M20, d. Clay mineral matter M17, e. Fractured Vitrinite and structured Fusinite -M14, f. Inertodetrinite in devolatized Colodetrinite -M13, g. Framboidal pyrite in Semifusinite -M12, h. Mineral matter -M11, i. Pyrite -M10, j. Vitrodetrinite, k. Colodetrinite -M7, I. Devolatized Vitrinite -M6, m. Preserved Fusinite and Inertodetrinite- M5, n. Vitrinite and inerts after desorption -M4, o. Degraded inerts - M3

\section{Figure 6}


Coal seams photomicrographs of the Landázuri 2 well after desorption gas process. a. Clay minerals M18, b. Pyrite filling Inertinite's spaces -M17, c. Devolatilized Vitrinite - M16, d. Clay minerals in fractured Vitrinite -M15, e. Colotelinite and Vitrodetrinite -M14, f. Inert in Colodetrinite -M11, g. Semifusinite's spaces filled with mineral matter -M10, h. Empty spaces in Colodetrinite and Semifusinite - M9, i. Inertodetrinite in Colodetrinite -M5, j. Pyrite in Fusinite -M3, k. Fusinite - M2
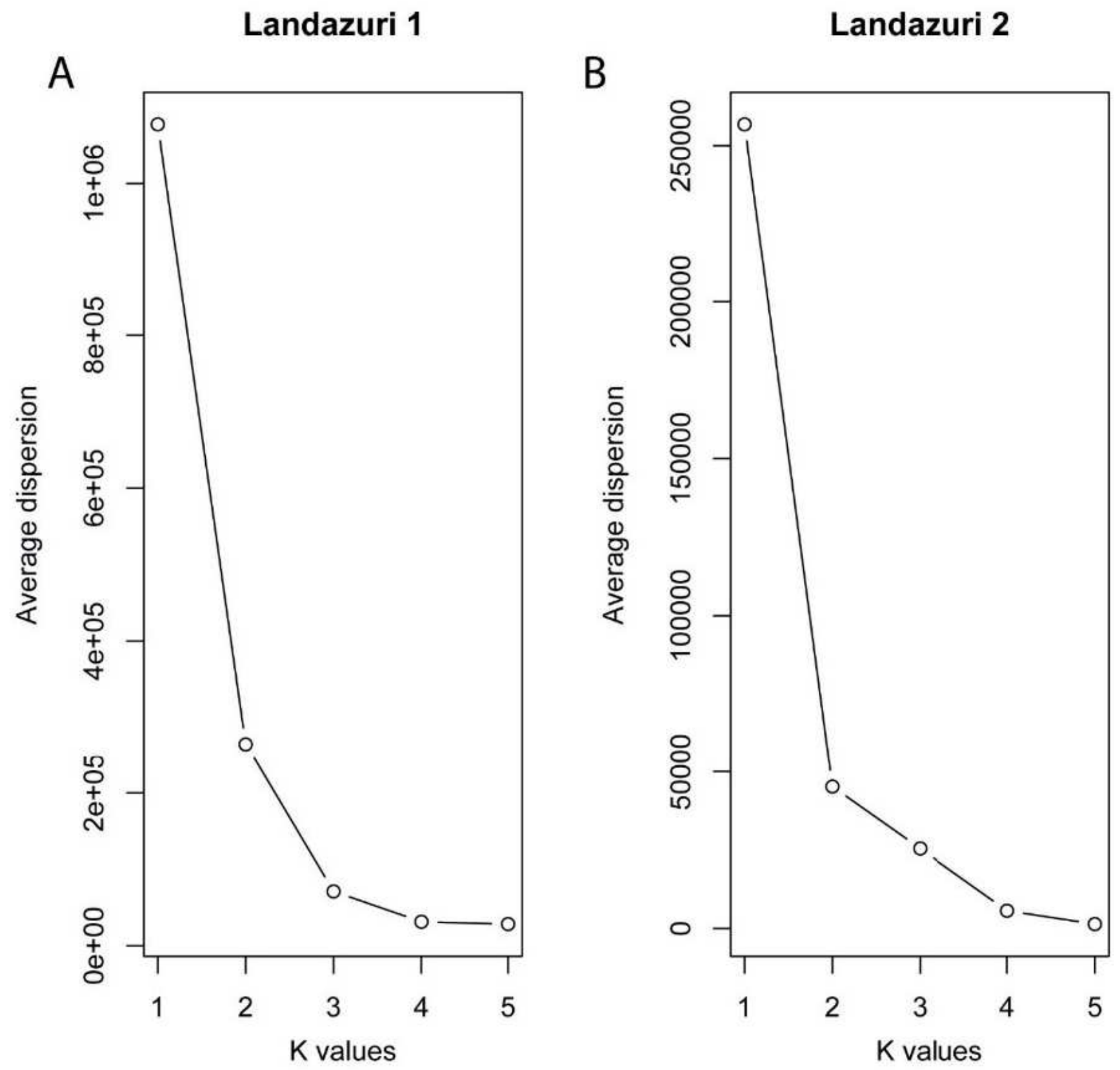

Figure 7

Elbow-plots for (A) Landázuri 1and (B) Landázuri 2 wells 

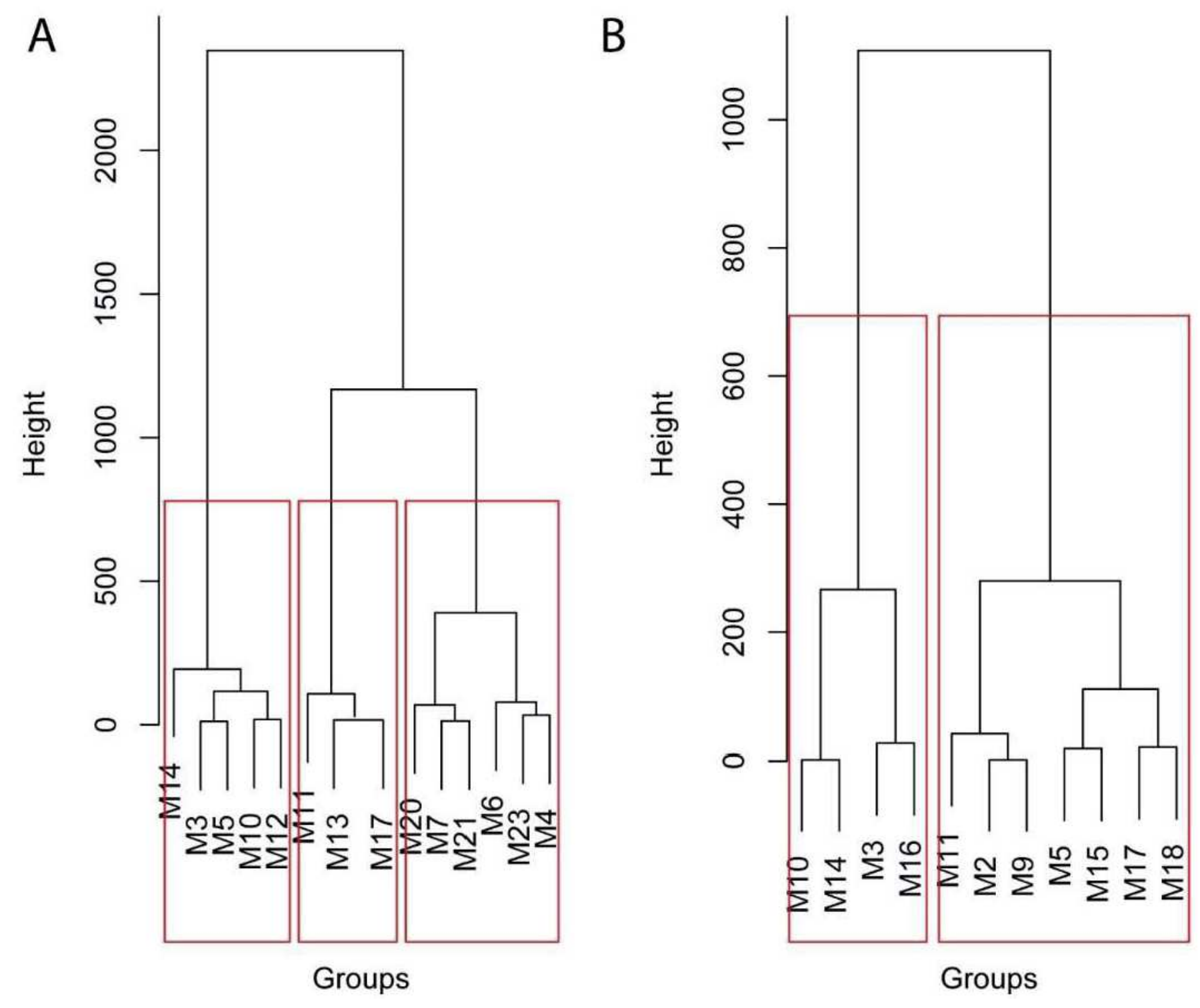

Figure 8

Dendograms showing results of cluster analysis (A) Landázuri-1 (B) Landázuri-2 wells 


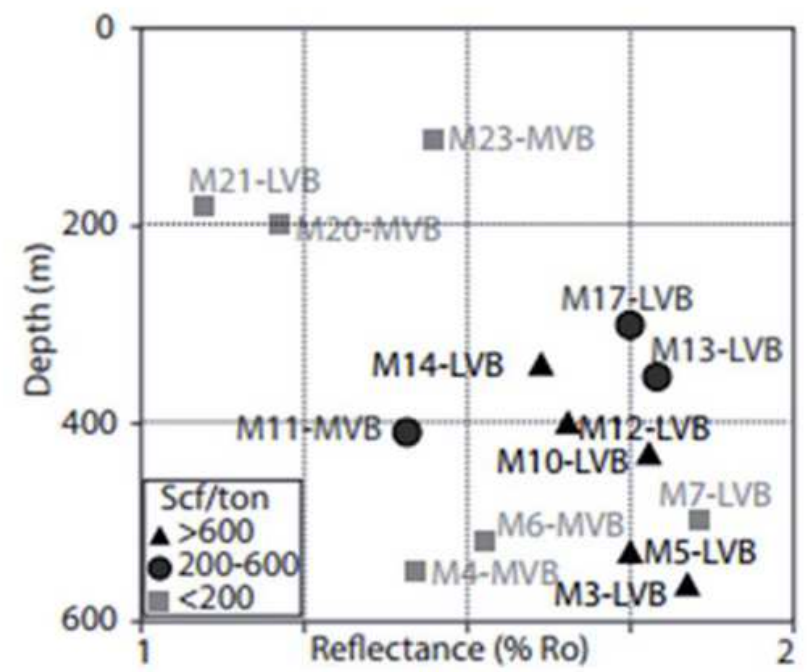

a.

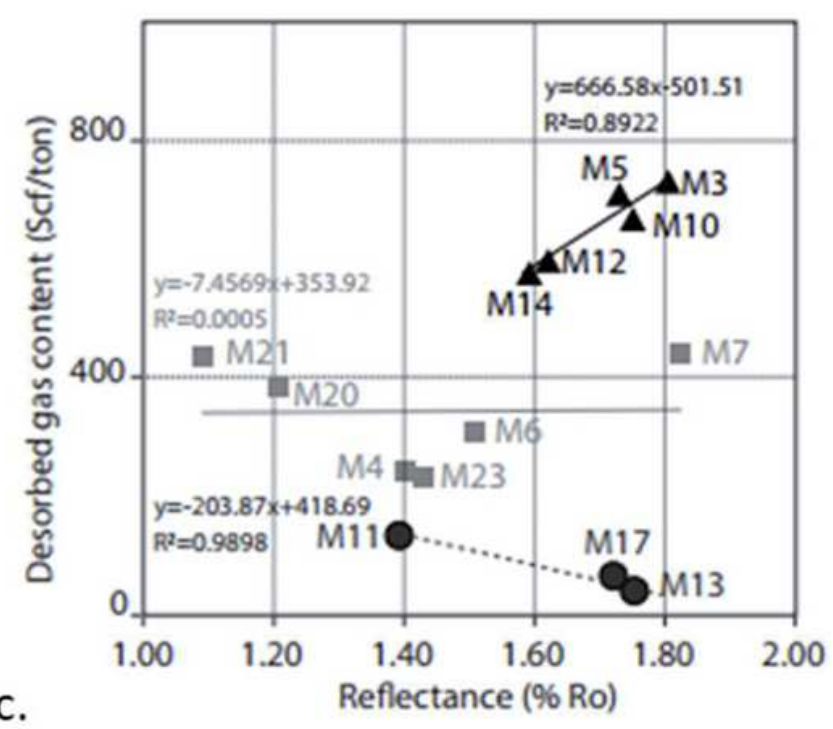

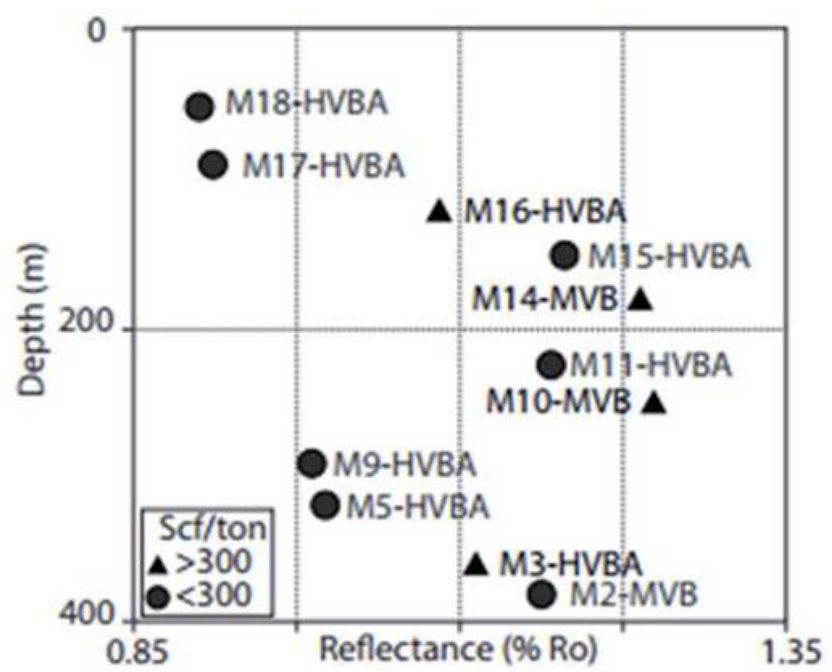

b.

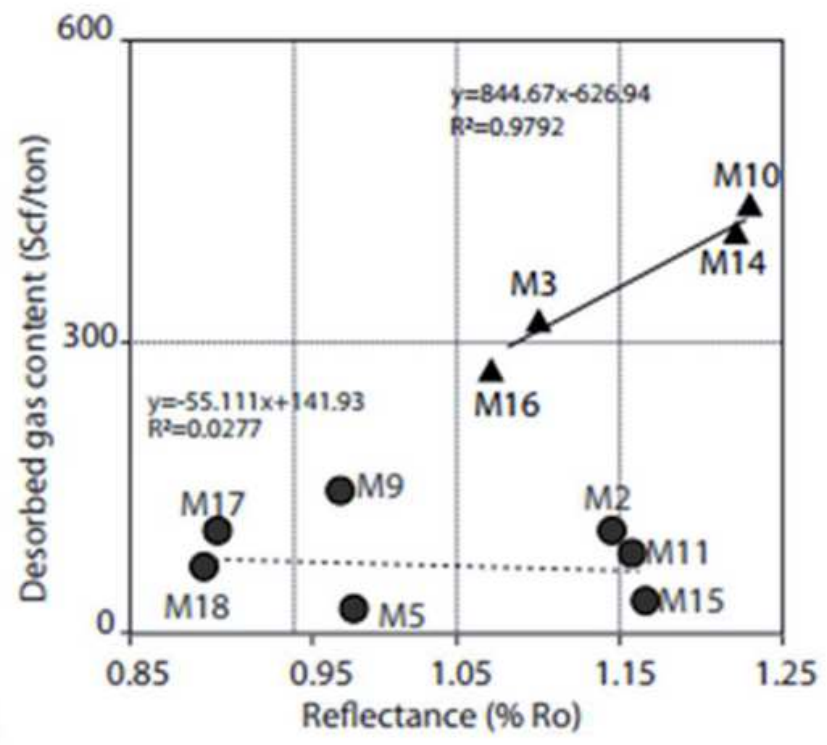

\section{Figure 9}

Coal rank (Ro) relation with depth and gas content measured (\%Ro) $(a, c)$ Landázuri-1 well. (b,d) Landázuri-2 well. HVBA- High Volatile Bituminous A, MVB- Medium Volatile Bituminous, - LVB Low Volatile Bituminous 

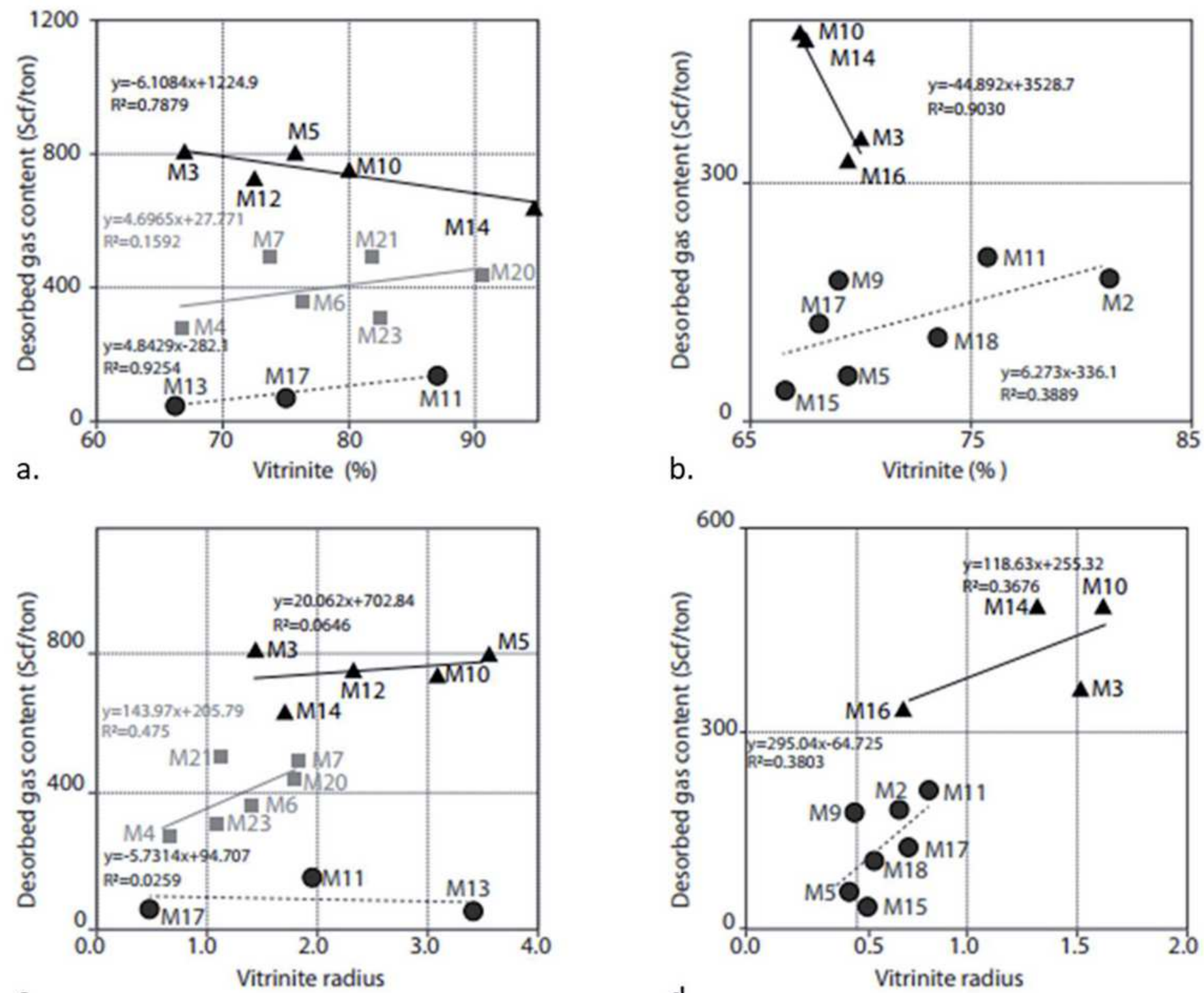

C.

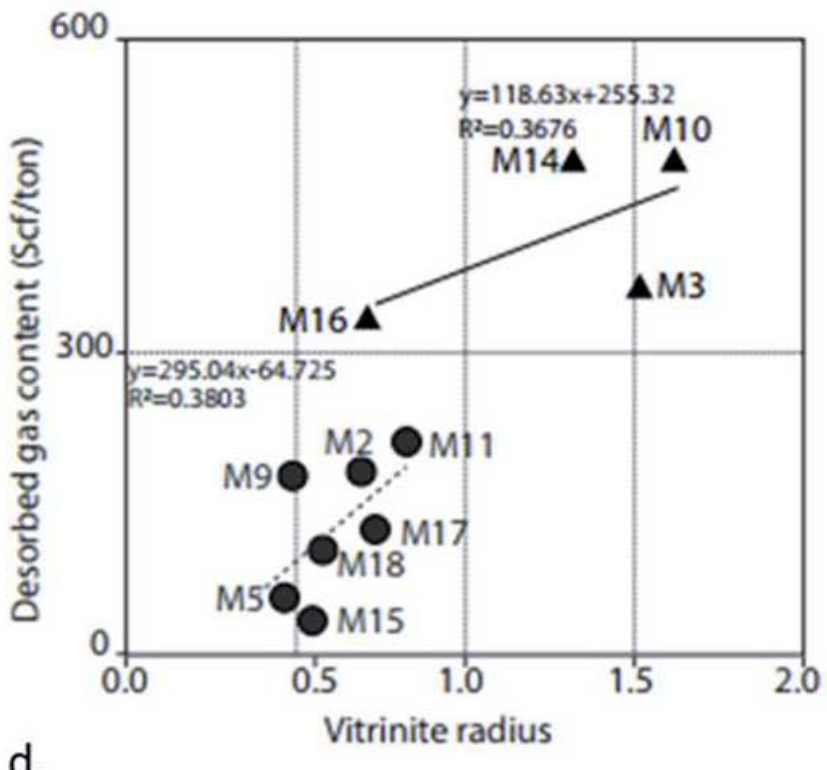

Figure 10

Relationship between Vitrinite percentage (fmmb) and the Vitrinite Radius with the gas content (SCF/ton) (a, c) Landázuri-1 well, (b,d) Landázuri-2 well 

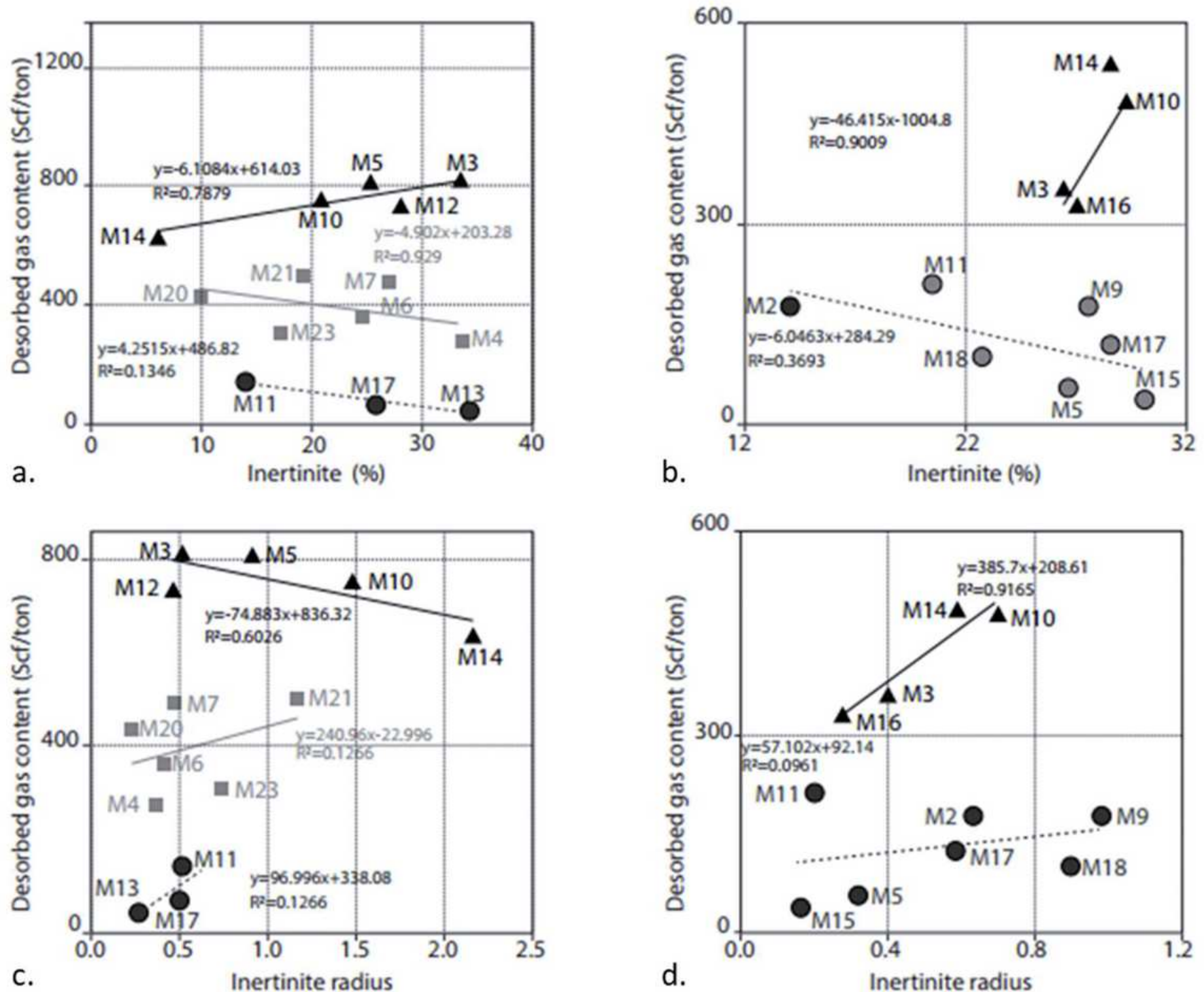

Figure 11

Relationship between Inertinite content (fmmb) and the Inertinite Radius with the gas content (scf/ton) (a, c) Landázuri-1 well, (b, d) Landázuri-2 well 

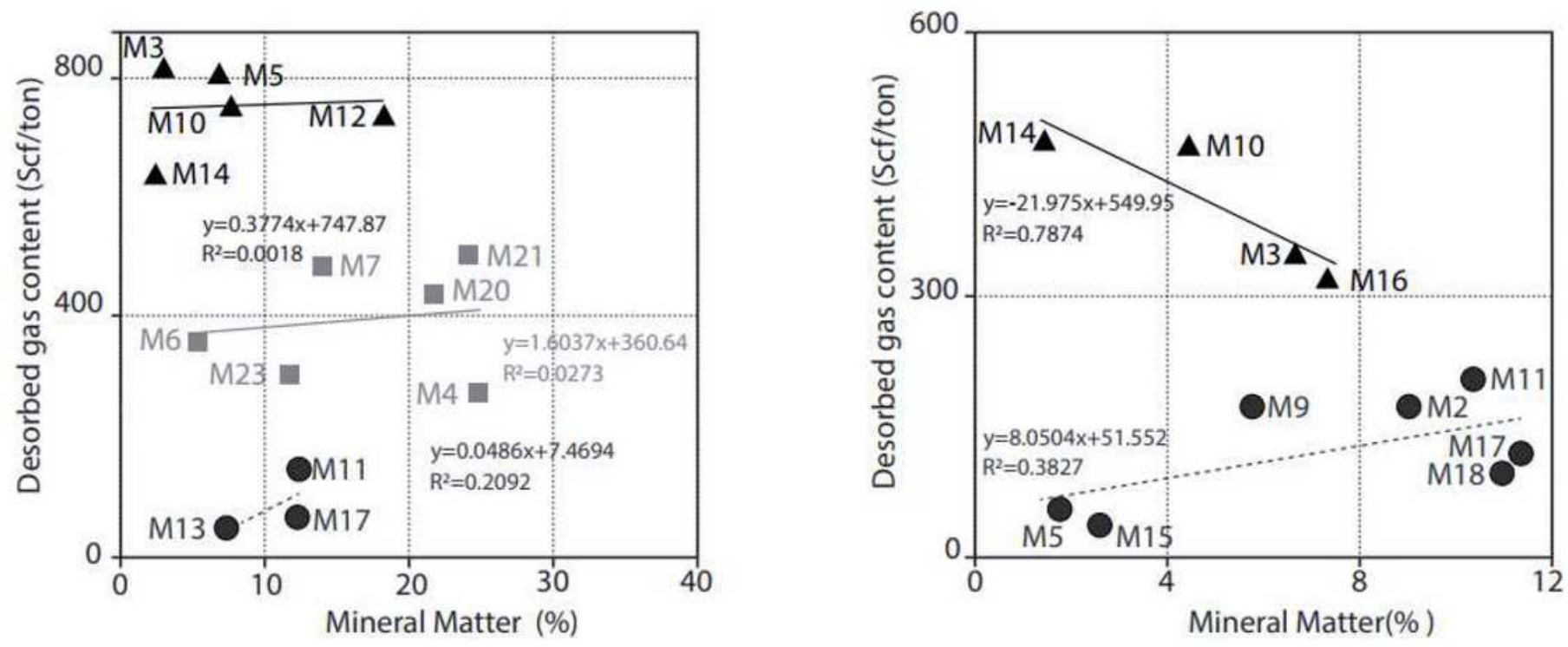

Figure 12

Relationship between mineral matter and the gas content (SCF/ton) (A). Landázuri 1 (B) Landázuri 2 

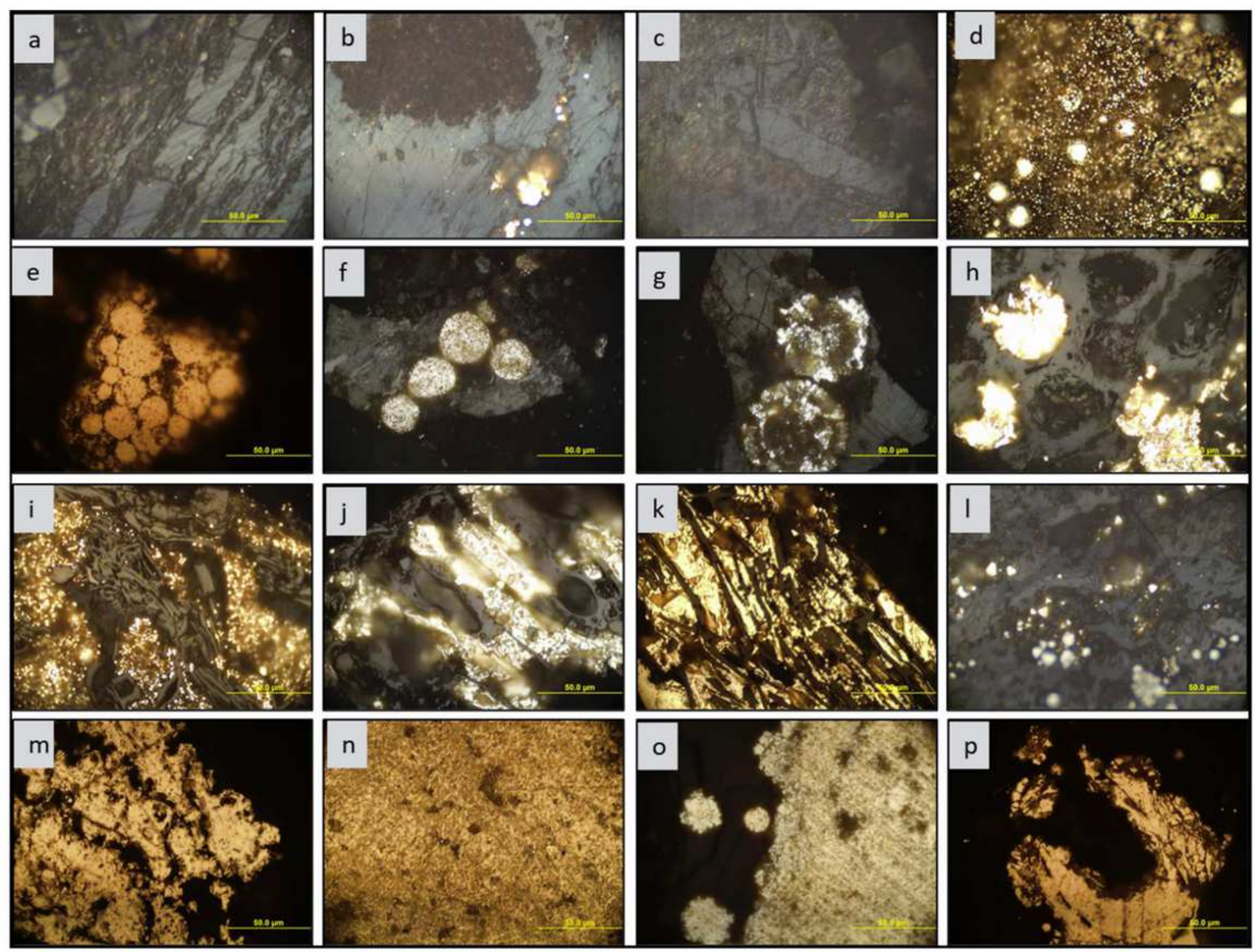

Figure 13

Microphotographs a. Clay minerals in M5- Landázuri-1, b. Clay minerals and pyrite-M17- Landázuri-2, c. Clay and others -M21- Landázuri-1, d. Framboidal pyrite -M17- Landázuri-2, e. Framboidal pyrite -M17Landázuri-2, f. Framboidal pyrite -M7-Landázuri-1, g. Framboidal pyrite -M7-Landázuri-2, h. Syngeneticdiagenetic pyrite -M3-Landázuri-2, i. Epigenetic pyrite -M17- Landázuri-2, j. Epigenetic pyrite-M2Landázuri-2, k. Epigenetic pyrite -M17-Landázuri-2, I. Syngenetic framboidal pyrite -M16-Landázuri-2, m. Diagenetic pyrite -M17-Landázuri-1, n. Diagenetic pyrite -M4- Landázuri-1, o. Diagenetic pyrite -M10Landázuri-1, p. Late diagenetic pyrite? -M17-Landázuri-2. 


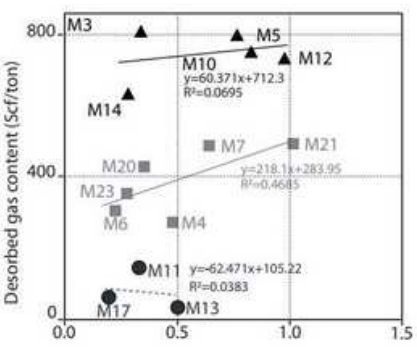

a. Tissue Preservation Index (TPI)
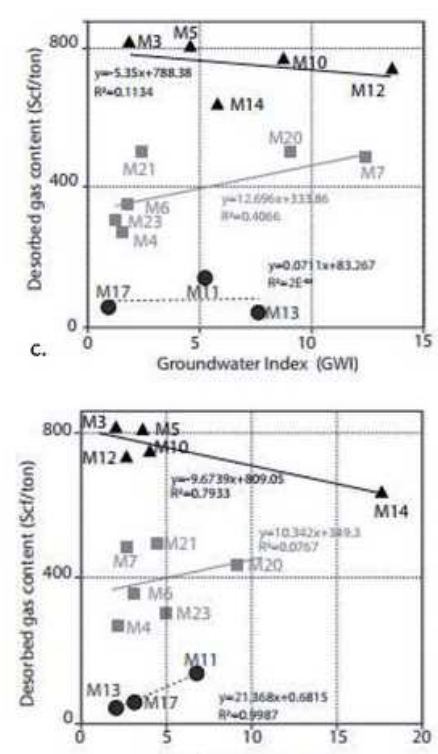

e. Gelification Index (GI)
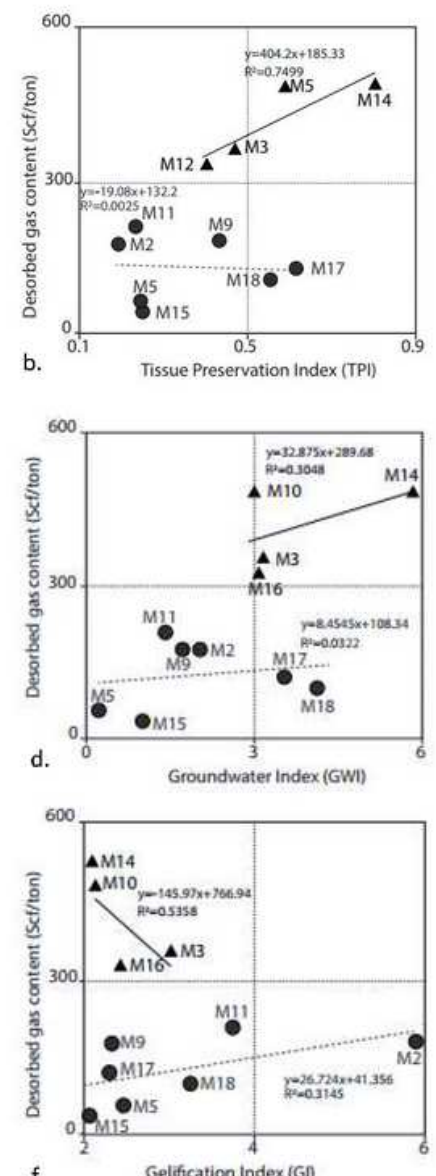

f. Gelification Index (G)
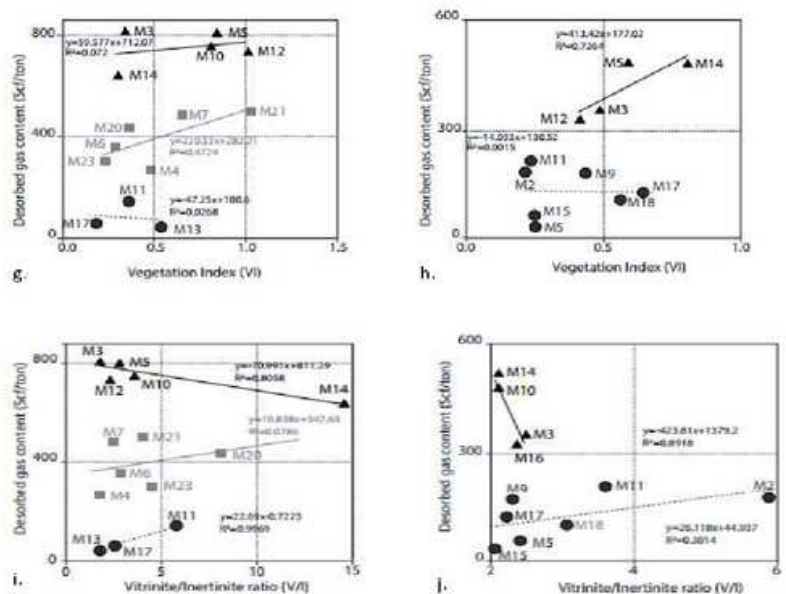

\section{Figure 14}

Relationships between gas content (SCF/ton) and petrographic indexes (TPI, GWI, GI, VI, and V/I). Relationships between gas content (SCF/ton) and petrographic indexes (TPI, GWI, GI, VI, and V/I)

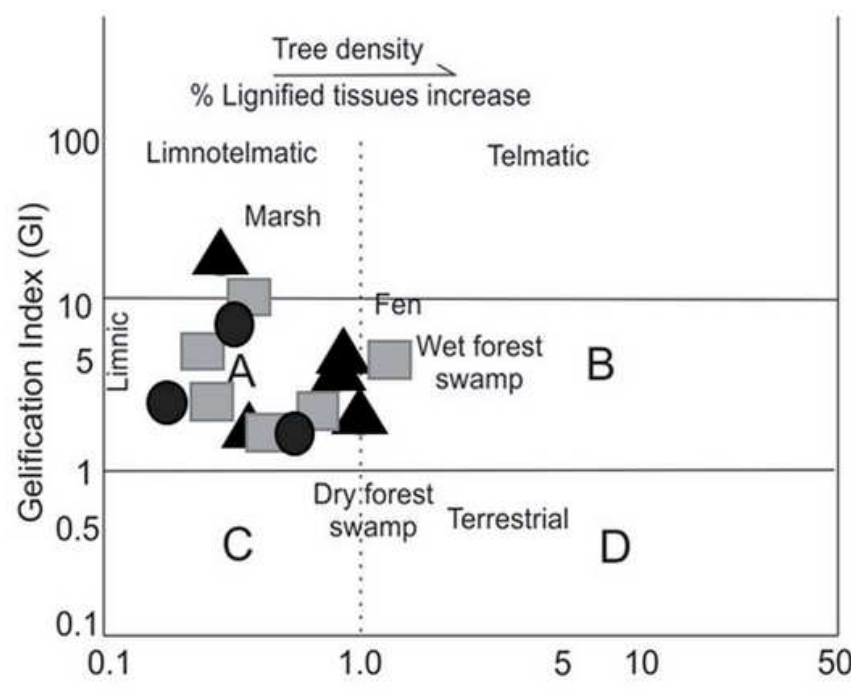

a.

Tissue Preservation Index (TPI)

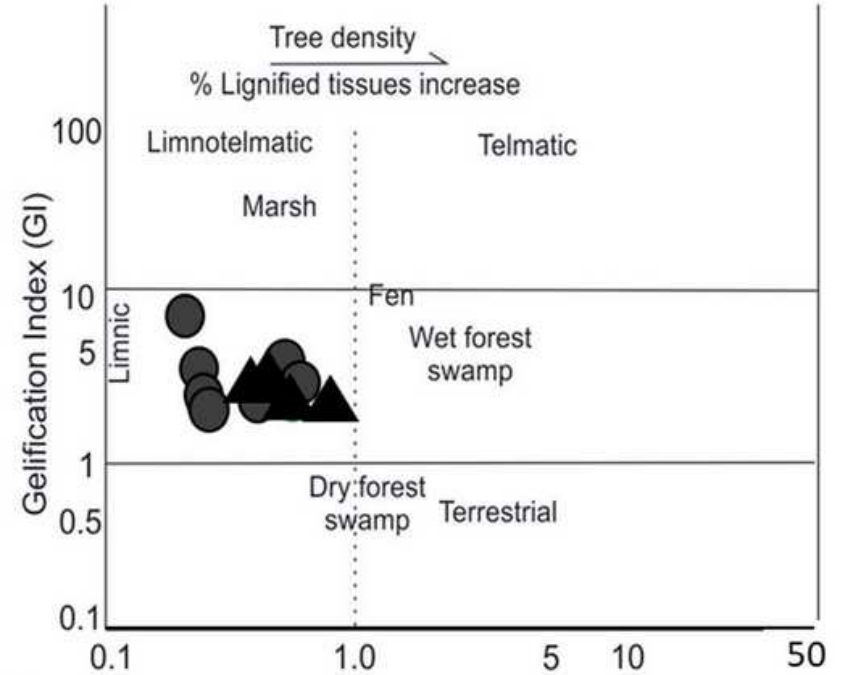

b.

Tissue Preservation Index (TPI) 
Figure 15

Coal facies (GI, TPI) Source: Diessel (1986) and modified by Kalkreuth et al. 1991. a. Landázuri 1. b. Landázuri 2 A. Vitrinite> Inertinite, Degraded Vitrinite> Structured Vitrinite B. Vitrinite> Structured Inertinite, Vitrinite> Degraded Vitrinite C. Inertinite> Vitrinite Inertodetrinite> Semifusinite- Fusinite D. Inertinite> Vitrinite Semifusinite+Fusinite> Inertodetrinite
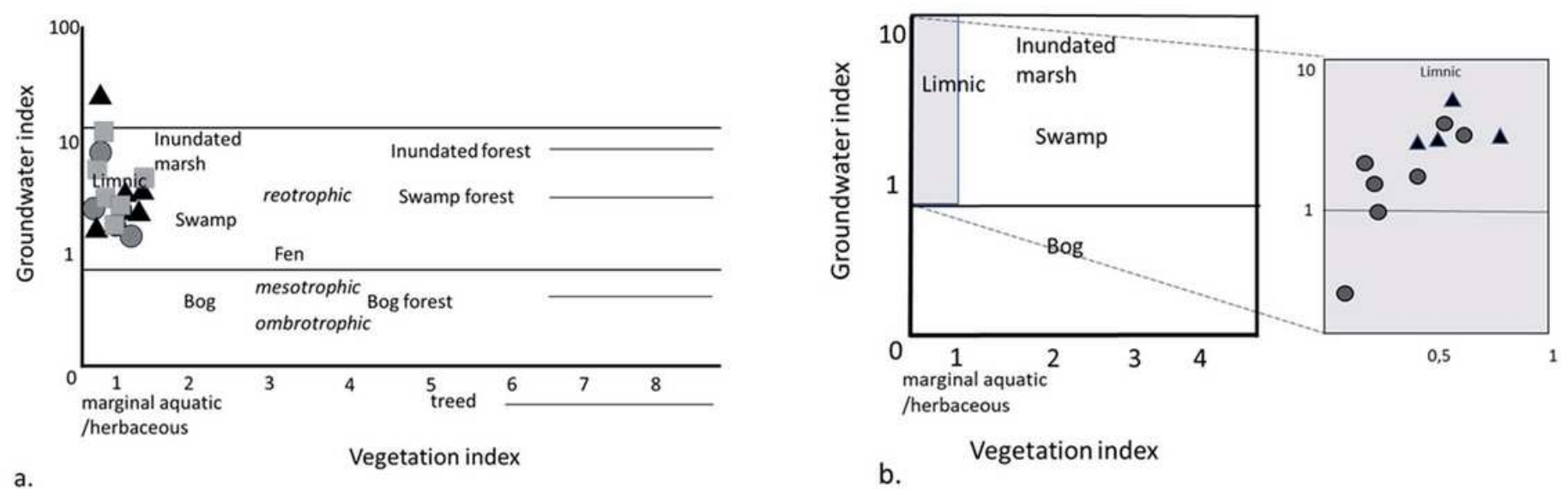

\section{Figure 16}

Coal facies (GWI, VI). a. Landázuri 1 b. Landázuri 2 (Modified from Calder et al., 1991) 

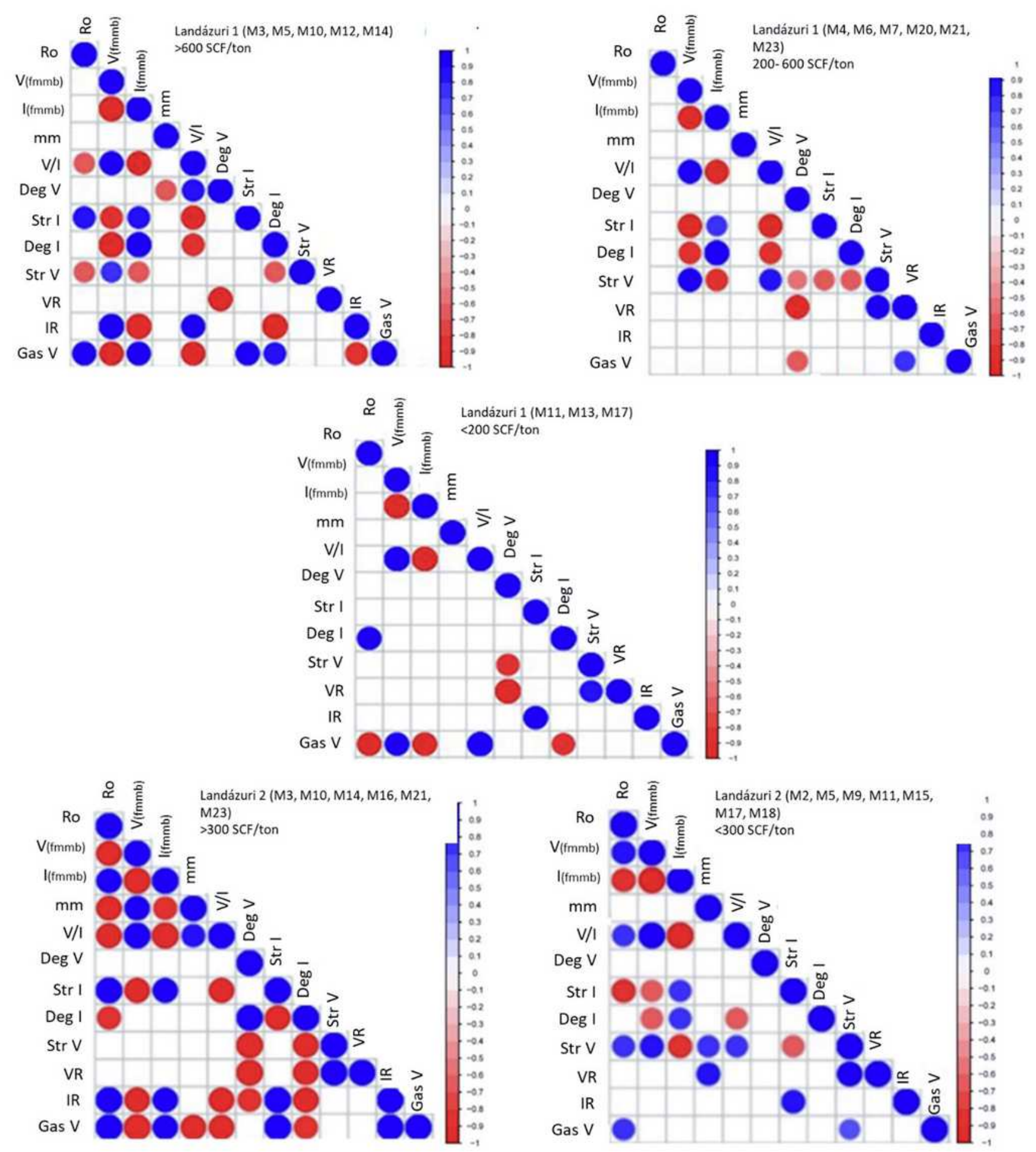

\section{Figure 17}

Pearson correlograms showing relationships between pairs of variables for Landázuri 1 and Landázuri-2 Ro- Average Vitrinite Reflectance, $\mathrm{V}$ fmmb - Vitrinite free mineral matter, I fmmb- Inertinite free mineral matter, mm- mineral matter, V/I- Vitrinite/Inertinite radius, Deg V- Degraded Vitrinite, Str I - Structured Inertinite, Deg I - Degraded Inertinite, Str V-Structured Vitrinite, RV- Vitrinite Radius, IR- Inertinite Radius, Gas V-Total gas volume measured SCF/ton 


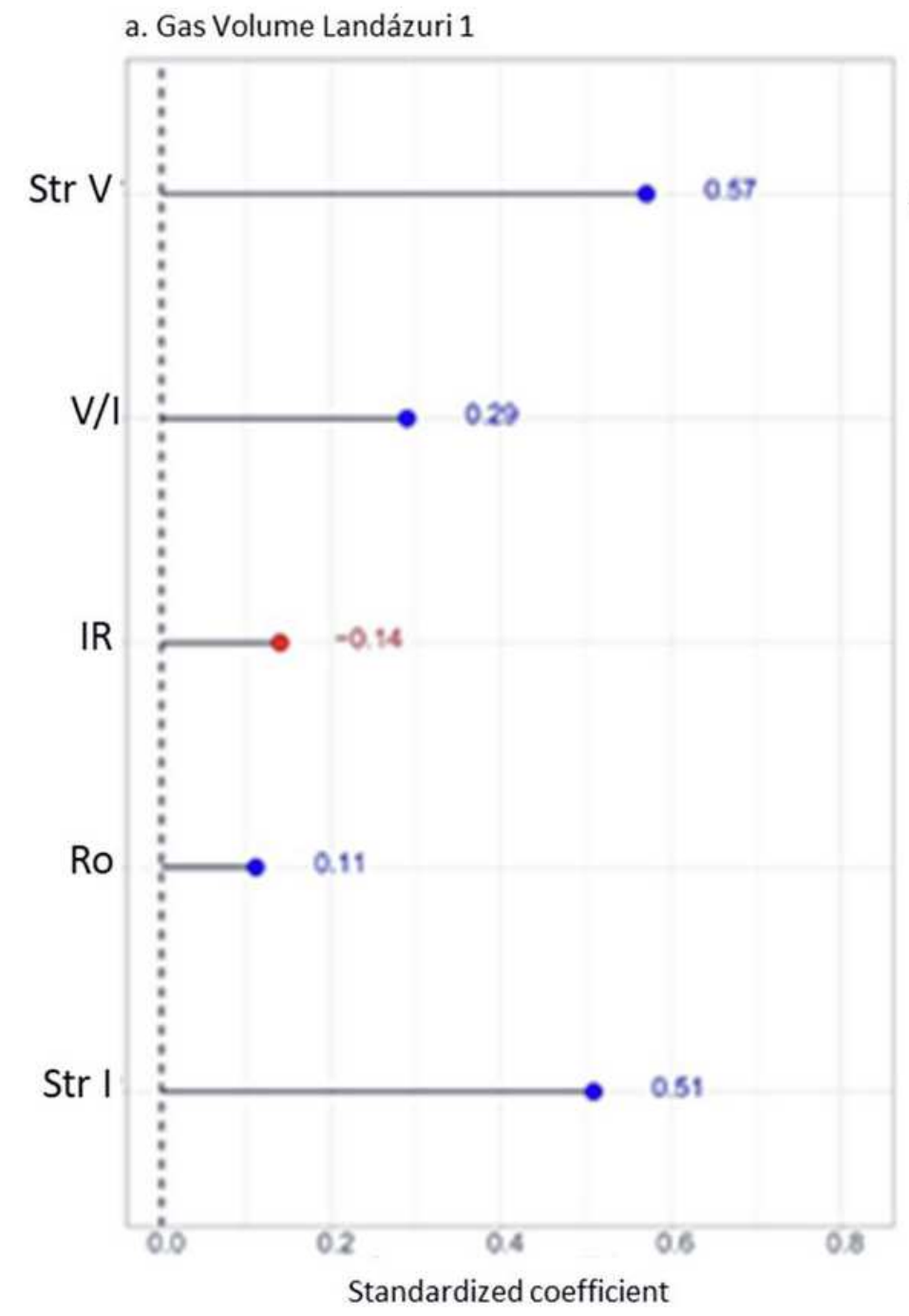

b. Gas Volume Landázuri 2

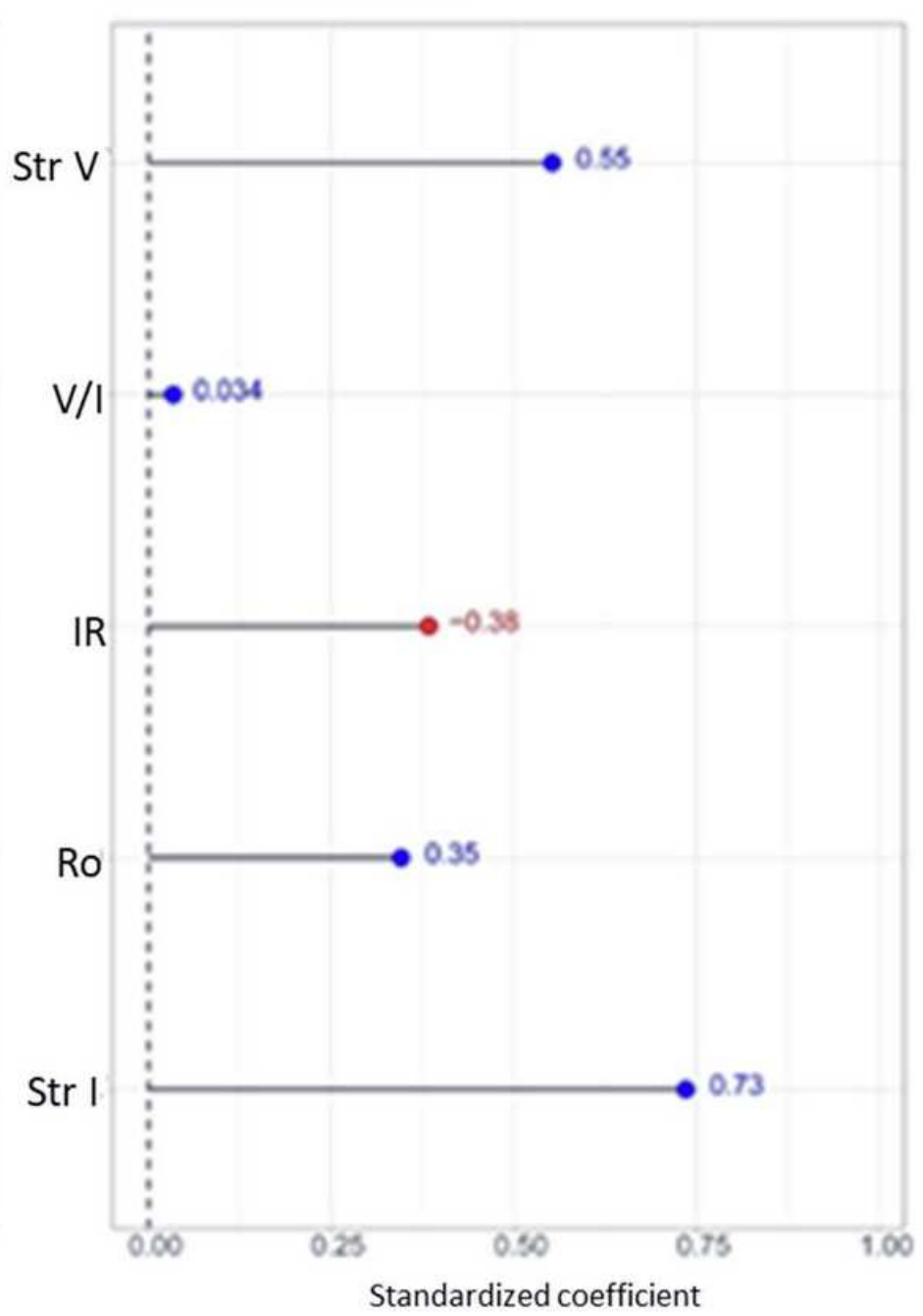

Figure 18

Behavior analysis of predictor variables (Str V, V/I, IR, Ro, Str I) versus response variable (Gas V) for the wells: a. Landazuri 1 and b. Landazuri 2 


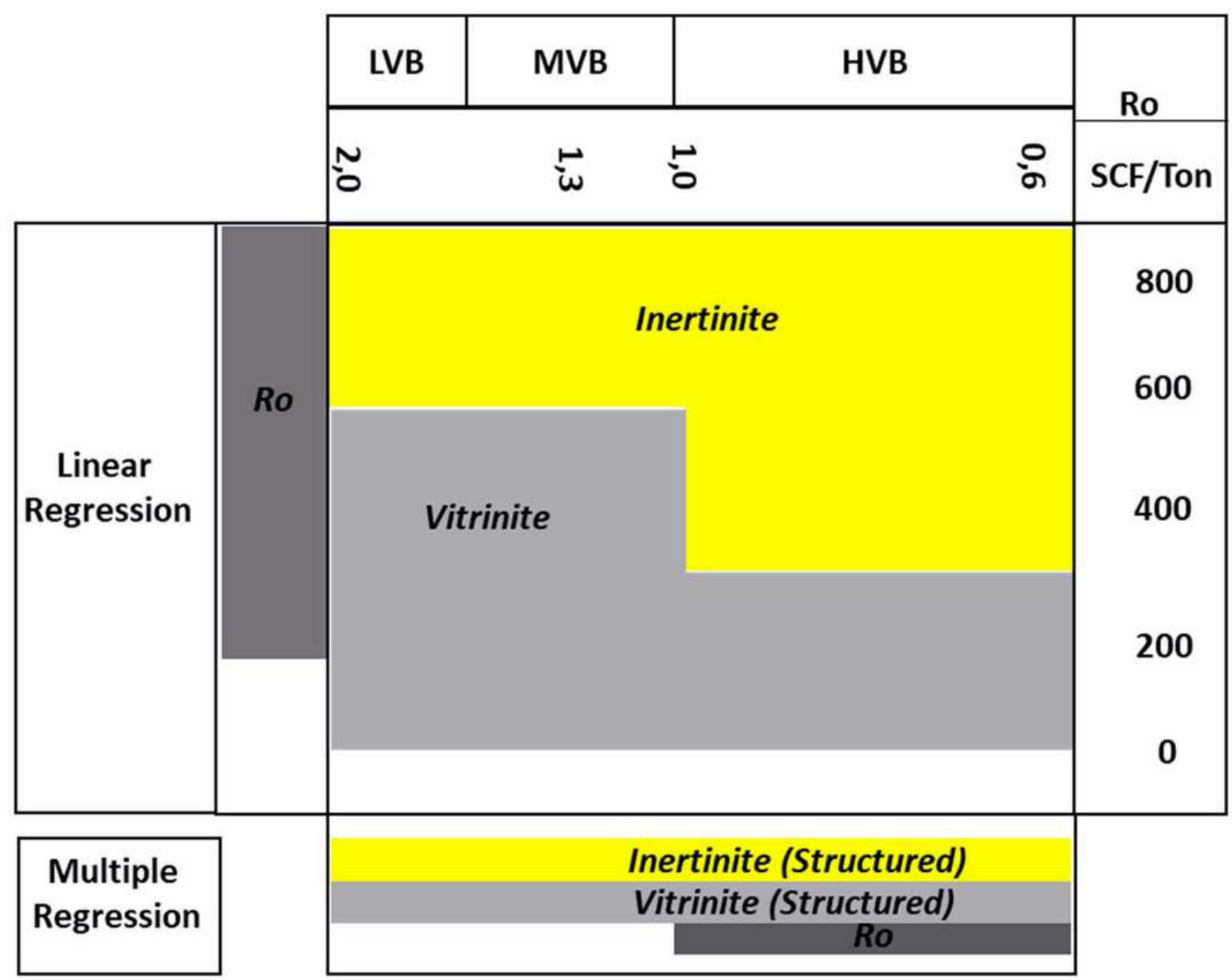

Figure 19

Synthesis of the importance of maceral groups and reflectance for the measured gas content

\section{Supplementary Files}

This is a list of supplementary files associated with this preprint. Click to download.

- GuatameetalTables.pdf 